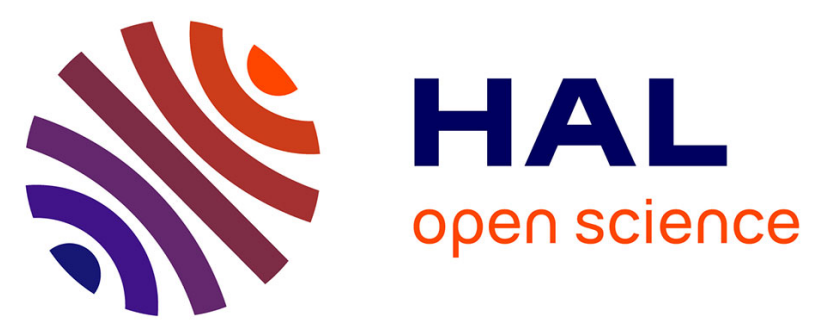

\title{
Vanadyl-type defects in Tavorite-like NaVPO4F: from the average long range structure to local environments
}

Edouard Boivin, Jean-Noel Chotard, Tahya Bamine, Dany Carlier, Paula

Serras, Verónica Palomares, Teófilo Rojo, Antonella Iadecola, Loic Dupont, Lydie Bourgeois, et al.

\section{To cite this version:}

Edouard Boivin, Jean-Noel Chotard, Tahya Bamine, Dany Carlier, Paula Serras, et al.. Vanadyl-type defects in Tavorite-like NaVPO4F: from the average long range structure to local environments. Journal of Materials Chemistry A, 2017, 5 (47), pp.25044-25055. 10.1039/C7TA08733K . hal-01664930

\section{HAL Id: hal-01664930 \\ https://hal.science/hal-01664930}

Submitted on 1 Feb 2021

HAL is a multi-disciplinary open access archive for the deposit and dissemination of scientific research documents, whether they are published or not. The documents may come from teaching and research institutions in France or abroad, or from public or private research centers.
L'archive ouverte pluridisciplinaire $\mathbf{H A L}$, est destinée au dépôt et à la diffusion de documents scientifiques de niveau recherche, publiés ou non, émanant des établissements d'enseignement et de recherche français ou étrangers, des laboratoires publics ou privés. 


\title{
Vanadyl-type defects in Tavorite-like $\mathrm{NaVPO}_{4} \mathrm{~F}$ : from the average long range structure to local environments.
}

\author{
Edouard Boivin ${ }^{a, b, c}$, Jean-Noël Chotard ${ }^{b, c, d}$, Tahya Bamine ${ }^{a, c}$, Dany Carlier ${ }^{a, c}$, Paula Serras ${ }^{e}$, \\ Verónica Palomares ${ }^{\text {e }}$, Teofilo Rojo ${ }^{\text {e,f }}$, Antonella ladecola ${ }^{c}$, Loïc Dupont ${ }^{\text {b,c,d }}$, Lydie Bourgeois ${ }^{\text {g,h }}$, \\ François Fauth ${ }^{\mathrm{i}}$, Christian Masquelier ${ }^{\mathrm{b}, \mathrm{c}, \mathrm{d}}$ and Laurence Croguennec ${ }^{\mathrm{a}, \mathrm{c}, \mathrm{d}, *}$
}

*Corresponding author (L. Croguennec): Laurence.Croguennec@icmcb.cnrs.fr 
${ }^{a}$ CNRS, Univ. Bordeaux, Bordeaux INP, ICMCB UPR 9048, F-33600 Pessac, France.

${ }^{\text {b}}$ Laboratoire de Réactivité et de Chimie des Solides, CNRS-UMR\#7314, Université de Picardie Jules Verne, F-80039 Amiens Cedex 1, France.

${ }^{c}$ RS2E, Réseau Français sur le Stockage Electrochimique de l’Energie, FR CNRS 3459, F-80039 Amiens Cedex 1, France.

${ }^{d}$ ALISTORE-ERI European Research Institute, FR CNRS 3104, F-80039 Amiens Cedex 1, France.

e Departamento de Química Inorgánica, Universidad del País Vasco UPV/EHU, P.O. Box 644, 48080, Bilbao, Spain.

${ }^{f}$ CIC ENERGIGUNE, Parque Tecnológico de Álava, Albert Einstein 48, ED. CIC, 01510 Miñano, Spain ${ }^{\mathrm{g}}$ Université de Bordeaux, ISM, Groupe de Spectroscopie Moléculaire, F-33405 Talence, France.

${ }^{\mathrm{h}}$ Bordeaux INP, ISM, CNRS UMR 5255, F-33405, Talence, France. 'CELLS - ALBA synchrotron, E-08290 Cerdanyola del Vallès, Barcelona, Spain. 


\section{ABSTRACT}

Tavorite-type compositions offer a rich crystal chemistry for positive electrodes in rechargeable batteries, among which $\mathrm{LiV}^{\mathrm{III}} \mathrm{PO}_{4} \mathrm{~F}$ has the highest theoretical energy density (i.e. 655 Wh. $\mathrm{kg}^{-1}$ ). In this article, we report for the first time the synthesis of the related Na-based phase crystallizing in the Tavorite-like structure. Its in-depth structural and electronic characterization was conducted by a combination of several techniques, spanning electron and X-ray powder diffraction as well as Infrared and X-ray absorption spectroscopy. The magnetic susceptibility measurement reveals an average oxidation state for vanadium slightly higher than $\mathrm{V}^{3+}$. This slight oxidation is supported by Infrared and X-ray absorption spectroscopies which highlight the presence of $\mathrm{V}^{4+}=0$ vanadyl-type defects leading to an approximated $\mathrm{NaV}^{\mathrm{III}}{ }_{0.85}\left(\mathrm{~V}^{\mathrm{IV}} \mathrm{O}\right)_{0.15}\left(\mathrm{PO}_{4}\right) \mathrm{F}_{0.85}$ composition. In this material, the profile of the diffraction lines is governed by a strong strain anisotropic broadening arising from the competitive formation between the ionic $\mathrm{V}^{3+}-\mathrm{F}$ and the covalent $\mathrm{V}^{4+}=\mathrm{O}$ bonds. This material shows a limited extraction of sodium, close to $15 \%$ of the theoretical capacity. Indeed, its electrochemical properties are strongly inhibited by the intrinsic low sodium mobility in the Tavorite framework. 


\section{INTRODUCTION}

The increasing mobility of populations and the need to fight against global warming are two reasons for which the electrochemical energy storage is one of the major issue of scientific researches both at the academic and industrial levels. Since its development and first commercialization in the 90 's, the Lithium-ion battery technology is widely used as a power source for mobile devices such as smartphones, laptops etc. The energy density delivered by the Lithiumion batteries, though, still cannot compete with the fossil energies as a power source for transportation applications such as electric and hybrid vehicles: indeed their high cost and limited autonomy are real penalties to their development. Most efforts in the field converge towards the same goals: the increase in energy and power densities with an improved safety in the charge state of the battery, a long range cyclability, and a reduction of the price moving towards sustainable raw materials ${ }^{1,2}$.

The lithium required for these applications is produced essentially from the concentration of lithium brines. Most of the Lithium resources are located in few countries such as China, Australia, Chili, Bolivia and Argentina. They are estimated to amount around ten millions of tons $\left(0.002\right.$ wt.\% of earth's crust $\left.{ }^{3,4}\right)$ and could be seen as limited considering the always growing global demand for Lithium-ion batteries. In order to propose alternatives to this technology and to control better possible huge variations of the Lithium price, the Sodium-Ion technology is seriously considered as a solution that will be rapidly mature. Indeed, sodium is one of the most abundant element in the earth's crust and oceans ( $2.5 \mathrm{wt} . \%$ of earth's crust and oceans $\left.{ }^{3,4}\right)$, and the materials chemistry and electrochemistry required to develop Sodium and Lithium-ion batteries are very similar.

At the academic level, the study of sodium intercalation compounds began in the 1980 s with that of a sodium layered oxide $\mathrm{Na}_{x} \mathrm{MO}_{2}$ by Delmas ${ }^{5}$ and a large panel of sodium based compounds are already identified to be potential candidates at the positive electrode of Sodium-ion batteries. Most of them are layered oxides $\mathrm{Na}_{x} \mathrm{MO}_{2}$, unstable in air, with a limited 
reversible capacity $(x \leq 1)$ within a wide potential window, detrimental to the energy density. ${ }^{6}$ Furthermore, due to the higher potential of $0.3 \mathrm{~V}$ for the $\mathrm{Na}^{+} / \mathrm{Na}$ redox couple compared to that of $\mathrm{Li}^{+} / \mathrm{Li}$, the energy density stored in Na-ion batteries will remain smaller without the development of high potential positive electrode materials to increase the voltage difference between both electrodes.

The development of sodium based polyanionic materials might be a solution. Indeed, the replacement in the host structures of oxygen anions by polyanionic groups $\left(\mathrm{PO}_{4}{ }^{3-}, \mathrm{SO}_{4}{ }^{2-} \ldots\right)$ increases the ionicity of the antagonist metal-oxygen bond compared to that observed in oxides and thus the voltage of a given redox couple. ${ }^{7,8}$ Among these polyanionic compounds, the most investigated for Sodium-ion batteries are vanadium phosphates such as $\mathrm{Na}_{3} \mathrm{~V}_{2}{ }_{2}\left(\mathrm{PO}_{4}\right)_{3}$, $\mathrm{Na}_{3} \mathrm{~V}_{2}{ }_{2}\left(\mathrm{PO}_{4}\right)_{2} \mathrm{~F}_{3}$ and $\mathrm{Na}_{3} \mathrm{~V}^{\prime \prime \prime}{ }_{2-\mathrm{y}}\left(\mathrm{V}^{\mathrm{IV}} \mathrm{O}\right)_{y}\left(\mathrm{PO}_{4}\right)_{2} \mathrm{~F}_{3-\mathrm{y}}$ (or also written $\left.\mathrm{Na}_{3} \mathrm{~V}_{2}\left(\mathrm{PO}_{4}\right)_{2} \mathrm{~F}_{3-\mathrm{y}} \mathrm{O}_{\mathrm{y}}\right){ }^{9-14}$ The composition $\mathrm{NaV}^{\text {III }} \mathrm{PO}_{4} \mathrm{~F}$ was already announced ${ }^{15-21}$, but never as a Tavorite structure in which transition metal octahedra $\left(\mathrm{VO}_{4} \mathrm{Y}_{2}\right)$ are sharing a bridging anion $\mathrm{Y}$ and form infinite chains [-Y- $\left.\mathrm{VO}_{4}-\mathrm{Y}\right]$, which are linked to each other through $\mathrm{PO}_{4}$ tetrahedra. Tavorite-type materials are widely studied, mainly as positive electrode materials for Li-ion batteries, but until now $\mathrm{NaV}^{\mathrm{III}} \mathrm{PO}_{4} \mathrm{~F}$ had never been reported despite the existence of the homeotype $\mathrm{NaV}^{\mathrm{IV}} \mathrm{PO}_{4} \mathrm{O},{ }^{22}$ but also that of the corresponding lithiated compounds, $\mathrm{LiV}^{\prime I I} \mathrm{PO}_{4} \mathrm{~F}$ and $\mathrm{LiV}^{\mathrm{IV}} \mathrm{PO}_{4} \mathrm{O}$, both of them showing interesting electrochemical properties. ${ }^{23,24}$ In this article, the synthesis, as well as the structural, microstructural and electrochemical properties of the new $\mathrm{NaV}^{\text {IIII }} \mathrm{PO}_{4} \mathrm{~F}$-type composition, are described in details.

\section{EXPERIMENT}

Synthesis was performed under hydrothermal conditions using $23 \mathrm{~mL}$ Parr Teflon reactors. The precursors used were vanadium (III) chlorine $\left(\mathrm{VCl}_{3}\right.$, Sigma-Aldrich, 97\%), sodium phosphate octahydrate $\left(\mathrm{Na}_{3} \mathrm{PO}_{4} .8 \mathrm{H}_{2} \mathrm{O}\right.$, Sigma-Aldrich, 97\%), phosphoric acid $\left(\mathrm{H}_{3} \mathrm{PO}_{4}\right.$, SigmaAldrich, $68 \%$ in water) and sodium fluorine (NaF, Sigma-Aldrich, $\leq 99 \%)$. The precursors were introduced as such in $23 \mathrm{~mL}$ Teflon vessels filled at $\sim 60 \%$. First synthesis trials were attempted by 
introducing stoichiometric amounts of the precursors to get the nominal composition of $\mathrm{NaVPO}_{4} \mathrm{~F}$ but this material was obtained pure only with the molar ratio $\mathrm{VCl}_{3} / \mathrm{H}_{3} \mathrm{PO}_{4} / \mathrm{Na}_{3} \mathrm{PO}_{4} / \mathrm{NaF}: 1 / 1.2 / 0.7 / 1.2$ (i.e. $\mathrm{Na} / \mathrm{V} / \mathrm{PO}_{4} / \mathrm{F}: 3.3 / 1 / 1.9 / 1.2$ ). The reactors were set in a furnace already at the temperature required $\left(240^{\circ} \mathrm{C}\right)$ for $24 \mathrm{~h}$, and were cooled down naturally to room temperature. The obtained powder was filtered, washed with water (to eliminate the precursors introduced in over-stoichiometry), rinsed with ethanol and dried at $60^{\circ} \mathrm{C}$ overnight.

Scanning electron microscopy (SEM) images were recorded with a FEl Quanta 200F microscope at $20 \mathrm{kV}$. Electron diffraction (ED) patterns and Transmission electron microscopy (TEM) images were obtained with a Tecnai G2 electron microscope operated at $200 \mathrm{kV}$. Samples were prepared by grinding the crystalline powder in a mortar in anhydrous ethanol and depositing drops of the suspension on a copper grid.

In order to confirm the chemical compositions of the samples, the $\mathrm{Na}, \mathrm{V}$, and $\mathrm{P}$ contents were determined using Inductively Coupled Plasma / Optical Emission Spectrometry (ICP-OES) and a Varian 720-ES Optical Emission Spectrometer after complete dissolution of the powders into a hydrochloric-nitric acid solution.

The average oxidation state of vanadium was determined from the measure of the sample's magnetization as function of temperature in the paramagnetic domain thanks to a Vibrating Sample Magnetometer (VSM) (in the 100-500K temperature range and with a heating rate of $10 \mathrm{~K} / \mathrm{min}$ ). The sample holder used was a sealed aluminum capsule in which the powder was immobilized thanks to a plug of glass fibers. The measured magnetic susceptibility was corrected from that of the sample holder (aluminum and glass fiber) based on a blank experiment, as well as from the diamagnetic one considering the diamagnetic susceptibility of each constituting ion ${ }^{25}$, in order to determine the paramagnetic susceptibility of our sample according to: $\left(\gamma_{\text {para }}\left(\mathrm{NaVPO}_{4} \mathrm{~F}\right)=\gamma_{\text {mes }}-\gamma_{\text {dia }}\left(\mathrm{NaVPO}_{4} \mathrm{~F}\right)-\gamma_{\text {blank }}\right)$. 
High angular resolution Synchrotron Powder X-ray diffraction (SXRPD) data were collected using the MSPD diffractometer at ALBA (Barcelona, Spain), in Debye-Scherrer geometry at $0.9540 \AA$ in the $2 \theta$ angular range of $1^{\circ}-53^{\circ}$ with a $0.006^{\circ}(2 \theta)$ step and an accumulation time of 5 minutes. The sample was sealed in a $0.5 \mathrm{~mm}$ diameter capillary. Diffraction data treatment, Rietveld refinement and Bond Valence Energy Landscape were performed using the FullProf Suite. ${ }^{26}$

Infra-red (IR) spectroscopy proved to be powerful tool to detect the presence of vanadyltype environments, frequently reported for Vanadium-based Tavorite compounds, ${ }^{27}$ and to demonstrate the absence of hydroxyl group, sometimes formed during the synthesis of fluorinated materials in aqueous media ${ }^{28}$. Diffuse reflectance IR spectroscopy was performed using a Thermo Optek Nicolet 6700 equipped with a DTGS detector, in the range of 400-4000 $\mathrm{cm}^{-1}$ (mid-IR). The samples were finely ground in a mortar with dried $\mathrm{KBr}$, the mass ratio between the active material and $\mathrm{KBr}$ being approximately 1:50. Finally, reflectance spectra were treated with the Kubelka-Munk law, which converts the reflectance to a signal proportional to the absorption coefficient.

Vanadium K-edge X-ray absorption spectroscopy (XAS) spectra were acquired at room temperature in transmission mode at the ROCK beamline in SOLEIL Synchrotron (France), using a vanadium foil as a reference for the energy calibration. A Si (111) channel-cut quick-Xas monochromator with a frequency of $2 \mathrm{~Hz}$ and an energy resolution of $0.2 \mathrm{eV}$ was used for this experiment. Powder samples were mixed uniformly in a cellulose matrix and pressed into pellets of $13 \mathrm{~mm}$ diameter, to obtain the vanadium K-edge step close to 1 . Several X-ray absorption scans were collected to ensure the reproducibility of the spectra and to obtain a high signal to noise ratio. The normalization and background subtraction were performed using the Demeter package. ${ }^{29}$

To determine the electrochemical properties of our $\mathrm{NaVPO}_{4} \mathrm{~F}$-type sample in laboratory sodium cells, electrodes were prepared using $80 \mathrm{wt} . \%$ of active material previously ball milled 
using a SPEX miller during 30 minutes, $15 \mathrm{wt} . \%$ of carbon (Super P) and $5 \mathrm{wt} . \%$ of polyvinylidene fluoride (PVDF). N-methyl pyrrolidinone was added to this mixture and the resultant slurry was casted on an Al foil and dried at $60^{\circ} \mathrm{C}$ during $24 \mathrm{~h}$. Discs (diameter $12 \mathrm{~mm}$ ) cut in this foil were cycled in coin cells vs. metallic sodium in galvanostatic mode at a rate of $\mathrm{C} / 50$ (one electron exchanged per transition metal in $50 \mathrm{~h}$ ). The electrolyte used was a $1 \mathrm{M}$ solution of $\mathrm{NaPF}_{6}$ in ethylene carbonate $(E C)$ and dimethyl carbonate $(D M C)$ in a 1:1 volume ratio. Sodium cells were cycled, in the high voltage domain between 2.5 and $4.5 \mathrm{~V} \mathrm{vs} \mathrm{Na}^{+} / \mathrm{Na}$ involving the $\mathrm{V}^{3+} / \mathrm{V}^{4+}$ redox couple. In order to determine if the reactions were kinetically limited or intrinsically limited (thermodynamically not favored), a comparative experiment was performed considering the Tavorite LiVPO ${ }_{4} \mathrm{~F}$ at the positive electrode of a sodium cell, prepared in the in situ cell described in ref ${ }^{30}$. The goal was here to investigate in situ by XRD the insertion reaction of sodium in an "optimized" $V^{\mathrm{IV}} \mathrm{PO}_{4} \mathrm{~F}$ showing excellent electrochemical properties in Lithium cells, and in fine to be able to decide between kinetics and thermodynamics limitations.

\section{RESULTS and DISCUSSION}

\subsection{SYNTHESIS}

By analogy with hydrothermal syntheses already reported for other Vanadium based Tavorite type materials, $\mathrm{HV}^{11 \mid} \mathrm{PO}_{4} \mathrm{OH}^{31}$, $\mathrm{LiV}^{1 \mathrm{~V}} \mathrm{PO}_{4} \mathrm{O}^{32}$ and $\mathrm{LiV}^{111} \mathrm{PO}_{4} \mathrm{OH}^{33}$, we obtained a Tavoritetype sodium vanadium (III) fluoride phosphate, which was to our knowledge not reported previously in the literature. Actually the composition $\mathrm{NaVPO}_{4} \mathrm{~F}$ was already announced by several authors ${ }^{15-21}$, but a careful inspection of the crystallographic data they provided reveals the formation of $\mathrm{Na}_{3} \mathrm{~V}_{2}\left(\mathrm{PO}_{4}\right)_{2} \mathrm{~F}_{3}$ or $\mathrm{Na}_{3} \mathrm{~V}_{2}\left(\mathrm{PO}_{4}\right)_{3}$ as major phases. Indeed, the XRD patterns of the compounds published in references ${ }^{15}$ (Figure 1a), ${ }^{16}$ (Figure 2), ${ }^{17}$ (Figure 2b) and ${ }^{18}$ (Figure 1) can be indexed in a $\mathrm{Na}_{3} \mathrm{~V}_{2}\left(\mathrm{PO}_{4}\right)_{2} \mathrm{~F}_{3}$-type unit cell and those published in references ${ }^{17}$ (Figure 2a), ${ }^{19}$ (Figure 5), ${ }^{20}$ (Figure 1 b) and ${ }^{21}$ (Figure 1) with a $\mathrm{Na}_{3} \mathrm{~V}_{2}\left(\mathrm{PO}_{4}\right)_{3}$-type unit cell. 
The Tavorite-type phase was obtained pure only for a synthesis duration of $24 \mathrm{~h}$ at least, and the rather large particles obtained have a needle-like shape with a wide size's distribution, as shown in Figure 1. In order to try to decrease the particles' size and thus to improve their electrochemical properties, the reduction of the synthesis duration was attempted (down to $5 \mathrm{~h})$. The materials obtained for shorter reaction times $(<24 \mathrm{~h})$ were in fact mixtures of $\mathrm{NaVPO}_{4} \mathrm{~F}$ and $\mathrm{Na}_{3} \mathrm{~V}_{2}\left(\mathrm{PO}_{4}\right)_{2} \mathrm{~F}_{3}$, the weight fraction of the Tavorite phase increasing from 65 wt.\% after $5 \mathrm{~h}$ of reaction time to 100 wt.\% after $24 \mathrm{~h}$ (as detailed in Figure $\mathbf{S 1}$ in supplementary information).

The chemical composition in $\mathrm{Na}, \mathrm{V}$ and $\mathrm{P}$ was determined to be $0.97(5): 1.03(5): 1.00(5)$ by ICP-OES and thus found to be very close to the expected $\mathrm{NaVPO}_{4} \mathrm{~F}$ composition. As oxygen and fluorine cannot be distinguished and titrated easily, the determination of the magnetic susceptibility allowed to check for the possible presence of oxygen defects (and thus of $\mathrm{V}^{4+}=\mathrm{O}$ vanadyl-type defects for charge compensation). ${ }^{34,35}$ As shown in Figure S2, the magnetic susceptibility determined for our sample is 0.905 emu.mol ${ }^{-1}$ and corresponds to a vanadium average oxidation state of 3.15 according to the theoretical Curie constants of $\mathrm{V}^{4+}$ (i.e. 0.375) and $\mathrm{V}^{3+}$ (i.e. 1.00). This result suggests a rather large substitution of oxygen for fluorine ( 15\%), and thus the formation of vanadyl-type defects as also already evidenced recently for the lithiated analogue, $\mathrm{LiVPO}_{4} \mathrm{~F}^{27,34}$ As it will be highlighted in the following these defects could be detected by different spectroscopy techniques (Infrared, XAS and NMR) and also indirectly, through their effects on the microstructure.

\subsection{ANALYSIS OF THE MICROSTRUCTURE}

The SXRPD pattern of the $\mathrm{NaVPO}_{4} \mathrm{~F}$-type phase can be indexed with a monoclinic cell described in the space group $C 2 / c(a=6.5646(1) \AA, b=8.4406$ (1) $\AA, c=7.3727$ (1) $\AA$, $\beta=$ $\left.117.847(1)^{\circ}, V / Z=90.302(6) \AA^{3}\right)$. The profile of the diffraction lines is governed by a strong anisotropic broadening, that can be explained by anisotropic size and/or strain effects. Considering the needle shape of the particles, the anisotropic size effect could appear as obvious. Nevertheless, as discussed previously, i.e. vanadyl-type defects could also be present in "NaVPO${ }_{4} \mathrm{~F}$ " and they could thus be at the origin of strains as recently observed for LiVPO ${ }_{4} \mathrm{~F}_{1 \text { - }}$ 
$\mathrm{y}_{\mathrm{y}} \mathrm{O}^{27}$ In order to precisely calculate the effect of the microstructure, the instrumental contribution of the diffractometer was determined using a standard sample $\left(\mathrm{Na}_{2} \mathrm{Ca}_{3} \mathrm{Al}_{2} \mathrm{~F}_{14}\right)$. The refinements reported in Figure $\mathbf{2}$ were performed considering: (i) an isotropic size and strain model to describe the line profile, (ii) an anisotropic size model, and (iii) an anisotropic strain model.

Obviously, the isotropic model does not allow to take into account the profile of the experimental diffraction lines. The anisotropic size model was used as described in the FullProf suite software for a monoclinic symmetry. ${ }^{36,37}$ It reveals, from the 3D rebuilding of the particles' shape (made applying the Sherrer's law to each family of reflections), a size effect that would be associated to a needle-like morphology of the particles. Their calculated sections were close to $0.7 \times 0.95 \mu \mathrm{m}^{2}$ and their elongation along the [010] direction. Surprisingly, this section is found larger than expected with dimensions corresponding to the biggest particles observed in Figure 1, whereas the smallest and more numerous ones should more strongly impact the profile. Considering the anisotropic strain model. It predicts that the strains are maximal along the direction [101] which is the propagation direction of the chains built on $\mathrm{VO}_{4} \mathrm{~F}_{2}$ octahedra. Indeed, the inspection of the microstructural parameters reveals that the families of reflections which are strongly affected by significant broadening are (h0h), (h00), (00l) and (hhh). It appears difficult to discriminate between the two anisotropic models. Nevertheless, TEM analyses were performed in order to determine the actual elongation direction of the needle-like particles observed by SEM and to examine how extended is the periodicity.

A TEM image of an isolated needle-like particle, with dimensions of the order of $100 \mathrm{~nm}$ width and $1 \mu \mathrm{m}$ long, is shown in Figure 3a. The elongation direction of the particles was found to be along the [1-10]. This direction is different from the [010] suggested by the microstructural analysis based on the 3D rebuilding of the particles' shape (Figure 2). This result reveals that the anisotropic size model cannot be retained to explain the microstructure, and thus that strains might be at the origin of the anisotropic broadening of the diffraction lines. Nevertheless, the high magnification image given in Figure $\mathbf{3 b}$ highlights a quasi-perfect long range ordering without any defects in the $(-1-10)^{*}$ plane of the reciprocal space. The electron 
diffraction pattern reported in Figure $3 c$ can be indexed in the monoclinic space group C2/c with cell parameters in good agreement with those obtained by X-ray diffraction. At least for these small size needles studied by TEM, no diffusion trails or dislocations were observed despite clear anisotropic microstructural effects probably associated to the presence of oxygen in partial substitution for fluorine in $\mathrm{NaVPO}_{4} \mathrm{~F}$. The Figure $\mathbf{3 d}$ highlights the matching between the highresolution image of the selected region and a simulation made thanks to the MacTempas software ${ }^{38}$ with a thickness of $500 \AA$ and a defocusing of $+100 \AA$ and considering the structure determined by SXRPD . Note that similar apparent discrepancies were observed for the lithiated analogue (i.e. $\mathrm{LiVPO}_{4} \mathrm{~F}$ ), containing in fact vanadyl-type defects perfectly identified by ${ }^{7} \mathrm{Li}$ NMR whereas they were not detected by TEM ${ }^{34}$.

Our in-depth analysis of the SXRPD pattern considering different microstructural models, the agreement factors obtained and our previous knowledge of Tavorite systems such as $\mathrm{LiVPO}_{4} \mathrm{~F}_{1-\mathrm{y}} \mathrm{O}_{\mathrm{y}}{ }^{14}$ led us to retain the strain broadening model to describe the SXRPD pattern of this material for the Rietveld refinement described here just after.

\subsection{STRUCTURAL DESCRIPTION}

Atomic positions were determined using the ab-initio structure solving method provided by the EXPO software. ${ }^{39}$ The result of the Rietveld refinement is given in Figure 4 and all the structural parameters and reliability factors are listed in Table 1. The structural description thus obtained is $(\mathrm{Na})_{4 e}(\mathrm{~V})_{4 c}\left\{(\mathrm{P})_{4 e}\left[\mathrm{O}_{8 f}\right]_{2}\right\} \mathrm{F}_{4 e}$, with vanadium on the inversion center of the $\mathrm{VO}_{4} \mathrm{~F}_{2}$ octahedra and both V-F bonds symmetrically equivalent along the chains, on the contrary to what is observed for $\mathrm{NaVPO}_{4} \mathrm{O}$. Indeed, the space group $\mathrm{C} 2 / \mathrm{c}$ used to describe $\mathrm{NaV}^{\text {III }} \mathrm{PO}_{4} \mathrm{~F}$ forbids the distortion of the octahedra around vanadium along the $d z^{2}$ orbital, whereas the space group $\mathrm{P} 2_{1}$ /c used to describe $\mathrm{NaV}^{\mathrm{IV}} \mathrm{PO}_{4} \mathrm{O}$ allows the distortion required for the formation of the vanadyl bond (i.e. the short $\mathrm{V}^{\mathrm{IV}}=\mathrm{O}$ bond). In order to determine the nature of the bridging anions (i.e. oxygen or fluorine, that cannot be distinguished by X-ray or neutron diffraction), bond valence sums (BVS) were calculated using the Zachariasen formula $\left[V_{i}=\Sigma_{j} s_{i j}=\sum \exp \left\{\left(d_{0}-\right.\right.\right.$ 
$\left.\left.\mathrm{d}_{\mathrm{ij}}\right) / 0.37\right\}$ ], $\mathrm{d}_{0}$ being a typical distance reported by Brown et al. ${ }^{40}$ for each couple of cation and anion (here $\mathrm{V}^{3+}$, and $\mathrm{F}^{-}$or $\mathrm{O}^{2-}$, respectively) and $\mathrm{d}_{\mathrm{ij}}$ being the distances determined from the Rietveld refinement and belonging to the first coordination sphere of an ion. The BVS value associated to the bridging anion was found to be smaller (1.34(1)) than those of the two other anions belonging to the equatorial plane of the octahedra (1.97(2), in average). This result is in agreement with the structures already reported for other existing Tavorite-like fluoride phosphate phases, with the fluorine atom bridging adjacent $\mathrm{MO}_{4} \mathrm{~F}_{2}$ octahedra along the chains. Nevertheless, the BVS value determined for the bridging anion is higher than the theoretical value of 1 and the one determined for vanadium is also found to be superior to 3 (i.e. BVS(V) = 3.11(2)). These BVS values is higher than expected, assuming the $\mathrm{NaVPO}_{4} \mathrm{~F}$ composition, but in very good agreement with the magnetic susceptibility measurements (i.e. $\mathrm{V}^{3.15+}$ ). That is explained by the partial replacement of fluorine by oxygen and thus the presence of vanadyltype defects in the structure. Indeed the BVS calculation being based on the average structure determination reveals thus the average oxidation state of "an ion" that can be in fact a distribution of ions in one site, such as here $\mathrm{O}^{2-}$ and $\mathrm{F}^{-}$in the $4 e$ anionic site or $\mathrm{V}^{3+}$ and $\mathrm{V}^{4+}$ in the $4 c$ cationic site.

The atomic arrangement in $\mathrm{NaVPO}_{4} \mathrm{~F}$ is illustrated in Figure $\mathbf{5 a}$ and the main distances and angles are summarized in Table 2. This crystal structure is built up by $\mathrm{VO}_{4} \mathrm{~F}_{2}$ octahedra which share common fluorine atoms in such way to form $\cdots V \cdots F \cdots V \cdots F \cdots V \cdots$ infinite chains running along [101]. These chains of octahedra are connected to each other via $\mathrm{PO}_{4}$ tetrahedra forming $\cdots \vee \cdots O \cdots P \cdots O \cdots \vee \cdots$ sequences. These corner-sharing polyhedra generate a threedimensional network within which the sodium ions occupy the hexagonal tunnels along the [110] direction. The phosphorus atom lies within a tetrahedron with $\mathrm{P}-\mathrm{O}$ distances in the range of $1.548-1.557 \AA$ and a polyhedron distortion parameters: $\Delta=8.40 \times 10^{-6}$ (whose the definition is provided in the caption of the Table 2). Vanadium lies within an octahedral site with a narrow range of V-O distances, $1.974(3)$ - 2.009(4) $\AA$, a V-F distance of 1.934(6) $\AA$ and a rather high distortion of the $\mathrm{VO}_{4} \mathrm{~F}_{2}$ octahedron $\left(\Delta=2.61 \times 10^{-4}\right)$ mostly due to the shorter $\mathrm{V}-\mathrm{F}$ distances along the $\mathrm{dz}^{2}$ orbitals of vanadium. A comparison with similar Tavorite vanadium phosphate 
compositions is required to fully understand the nature of the bonds observed along the chains of octahedra, depending on the bridging anion. The $\mathrm{V}^{3+}$-rich compounds, $\mathrm{LiV}^{\prime \prime \prime} \mathrm{PO}_{4} \mathrm{~F}, \mathrm{LiV}^{\mathrm{III}} \mathrm{PO}{ }_{4} \mathrm{OH}$ and $\mathrm{HV}^{\prime \prime \prime} \mathrm{PO}_{4} \mathrm{OH}$, show constant bond lengths along their chains: shorter (1.98-1.99 $\AA$ ) for $\mathrm{V}-\mathrm{F}^{41}$, intermediate (2.00-2.03 $\AA$ ) for $\mathrm{V}-\{\mathrm{OH}\}^{33}$, and longer (2.15 $\AA$ ) for $\mathrm{V}-\left\{\mathrm{OH}_{2}\right\}^{31}$. Therefore, the shorter V-F distances observed in $\mathrm{NaVPO}_{4} \mathrm{~F}$ (i.e. $1.93 \AA$ vs. 1.98-1.99 $\AA$ in $\mathrm{LiVPO}_{4} \mathrm{~F}$ ) could be explained by the formation of local vanadyl-type (i.e. $\mathrm{V}^{4+}=\mathrm{O}$ ) defects. Indeed, related $\mathrm{V}^{4+}$ phase $\mathrm{NaVPO}_{4} \mathrm{O}$ exists, with an alternation between short and long bonds along the chains (1.68 and $2.09 \AA$ respectively ${ }^{22}$ ). As $\mathrm{X}$-ray diffraction is only able to describe an average structure, the partial replacement of ionic $\mathrm{V}^{3+}-\mathrm{F}$ bonds by very covalent $\mathrm{V}^{4+}=\mathrm{O}$ bonds actually tends to decrease the average distances.

The unique sodium site observed in $\mathrm{NaVPO}_{4} \mathrm{~F}$ is surrounded by six oxygens and one fluorine, in a distorted $\mathrm{NaO}_{6} \mathrm{~F}$ polyhedron with $\mathrm{Na}-\mathrm{X}$ distances ranging between 2.17 and $2.76 \AA$ $\left(\Delta=6.84 \times 10^{-3}\right)$ with an isotropic Debye-Waller factor ( $\left.B_{\text {iso }}\right)$ associated to sodium of 3.3(2) $\AA^{-2}$. The BVS associated for $\mathrm{Na}^{+}$cation is also in disagreement with its oxidation state (i.e. BVS = $1.26(1))$, that could arise from the partial substitution of fluorine by oxygen.

In order to get more insights into the possible pathways for sodium diffusion, the Bond Valence Energy Landscape (BVEL) was calculated using to the Bondstr software provided in the Fullprof suite. ${ }^{26}$ This empirical method based on the bond valence theory simulates the possible diffusion pathways considering a given energy to activate the movement of $\mathrm{Na}^{+}$ions, this energy being commonly of $1.6 \mathrm{eV}$ for polyanionic compounds. ${ }^{42}$ It appears that in these conditions sodium diffusion is limited inside the $\mathrm{NaVPO}_{4} \mathrm{~F}$-type framework (Figure 5b). Actually, as illustrated in more details in the supplementary information, a value of $3 \mathrm{eV}$ is necessary to make possible sodium diffusion from one site to another and to obtain a zig-zag sodium diffusion pathway parallel to the octahedral chains along the [101] (Figure S3). As the particle's shape is needle-like and elongated along [1-10] (according to TEM), the direction along [101] (i.e. at $75^{\circ}$ with [1-10]) corresponds to a rather short diffusion path through the solid for the $\mathrm{Na}^{+}$ ions: this morphology is thus the most appropriate to try to counterbalance the low intrinsic conductivity estimated by BVEL and to get despite of that good electrochemical properties. 
The diffraction study has thus revealed the formation, for the first time, of a $\mathrm{V}^{\text {III }}$-rich $\mathrm{NaVPO}_{4}$ F-type phase crystallizing in the Tavorite-like structure. Magnetic susceptibility measurements and the BVS suggest a partial oxygen substitution for fluorine leading to the formation of vanadyl-type defects and thus to the approximated $\mathrm{NaV}_{0.85}\left(\mathrm{~V}^{\mathrm{IV}} \mathrm{O}\right)_{0.15}\left(\mathrm{PO}_{4}\right) \mathrm{F}_{0.85}$ composition. These defects are at the origin of strains within the framework arising from the competitive formation between the strongly ionic $\mathrm{V}^{\mathrm{III}}-\mathrm{F}$ bond and the highly covalent $\mathrm{V}^{\mathrm{IV}}=\mathrm{O}$ one along the chains of vanadium octahedra. Nevertheless, these strains could not be detected by TEM. In order to elucidate this contradiction, further characterization of the local environments around vanadium was conducted by combining ${ }^{23} \mathrm{Na},{ }^{19} \mathrm{~F}$ and ${ }^{31} \mathrm{P}$ MAS Nuclear Magnetic Resonance (NMR), diffuse reflectance infrared and X-ray absorption spectroscopies. However, without the support of a theoretical study by DFT calculations of $\mathrm{NaVPO}_{4} \mathrm{~F}_{1-\mathrm{y}} \mathrm{O}_{\mathrm{y}}{ }^{35}$, the interpretation of the NMR spectra reported and discussed in the supplementary information (Figure S4) was not straightforward, but the presence of vanadyl-type defects cannot be excluded. Hereafter we have thus chosen to focus the discussion on the IR and XAS results.

\subsection{THE NATURE OF THE DEFECTS}

The Mid-IR diffuse reflectance spectrum of "NaVPO ${ }_{4} \mathrm{~F}$ " (i.e. approximated $\mathrm{NaV}^{\prime \prime \prime}{ }_{0.85}\left(\mathrm{~V}^{\mathrm{IV}} \mathrm{O}\right)_{0.15}\left(\mathrm{PO}_{4}\right) \mathrm{F}_{0.85}$ composition) is compared to those of $\mathrm{LiVPO}_{4} \mathrm{~F}$ and $\mathrm{LiVPO}_{4} \mathrm{~F}_{0.92} \mathrm{O}_{0.08}$ (from ref. ${ }^{27}$ ) in Figure 6, the main contributions and their assignments are listed in Table S1. The absence of signal around $3500 \mathrm{~cm}^{-1}$ evidences the absence of hydroxyl groups, ${ }^{43}$ frequently reported for fluorinated compounds obtained by hydrothermal synthesis. ${ }^{28}$ The $\mathrm{PO}_{4}$ stretching region, between 950 and $1200 \mathrm{~cm}^{-1}$, is characterized by three main bands around 983, 1056 and $1102 \mathrm{~cm}^{-1}$ (as highlighted in inset) and by two additional bands, smaller in intensity, at $950 \mathrm{~cm}^{-1}$ (as a shoulder) and $1185 \mathrm{~cm}^{-1}$. Due to the symmetry of the phosphate group imposed by the $\mathrm{C} 2 / \mathrm{c}$ space group of $\mathrm{NaVPO}_{4} \mathrm{~F}$, only one symmetric and three antisymmetric modes are expected ${ }^{44}$ but vanadyl-type defects modify the $\mathrm{PO}_{4}$ local symmetry and give rise to additional contributions. 
The signal observed at $881 \mathrm{~cm}^{-1}$ can be assigned to a vanadyl-type bond vibration ${ }^{27,33}$ (i.e. to a short $V^{\mathrm{IV}}=\mathrm{O}$ bond), as it exists in $\mathrm{NaV}^{\mathrm{IV}} \mathrm{PO}_{4} \mathrm{O}$ described in the $P 2_{1} / c$ space group with alternative long and short distances $\mathrm{O}---\mathrm{V}=\mathrm{O}$ along the chains. The average structure of $\mathrm{NaV}^{\text {III }} \mathrm{PO}_{4} \mathrm{~F}$ is described in the $\mathrm{C} 2 / \mathrm{C}$ space group having constant F--V--F distances along the chains, hence the presence of the vibration at $881 \mathrm{~cm}^{-1}$ is the signature of vanadyl-type local defects. The higher intensity of the $\mathrm{V}=\mathrm{O}$ stretching contribution detected in " $\mathrm{NaVPO}_{4} \mathrm{~F}$ ", in comparison with the one observed in $\mathrm{LiVPO}_{4} \mathrm{~F}$, highlights a higher concentration of vanadyl-type defects in the sodium phase, estimated to be $15 \%$ from the magnetic measurements.

Normalized Vanadium K-edge X-ray absorption near edge structure (XANES) spectra for Tavorite-type compositions "NaVPO${ }_{4} F$ ", $\mathrm{LiVPO}_{4} \mathrm{~F}$ and $\mathrm{LiVPO}_{4} \mathrm{~F}_{0.92} \mathrm{O}_{0.08}$ are reported in Figure 7. These spectra exhibit a pre-edge absorption feature followed by a rising absorption edge showing a shoulder and culminating in a strong peak at $\sim 5485 \mathrm{eV}$. This strong peak has been assigned to the dipole-allowed transition $1 \mathrm{~s}$ to $4 \mathrm{p}$, the lower-energy shoulder as the $1 \mathrm{~s}-4 \mathrm{p}$ shakedown transition, and the pre-edge feature as the transition $1 \mathrm{~s}$ to $3 \mathrm{~d} .{ }^{45}$ The $1 \mathrm{~s}$ to $3 \mathrm{~d}$ transition is strictly forbidden in perfectly regular $\mathrm{VO}_{6}$ octahedra but becomes dipole allowed when the inversion center is broken. In this case, the distortion of the octahedral local symmetry leads to a $V 3 d-4 p$ orbital mixing and thus to an overlap of the $V 3 d$ orbitals with the $2 p$ orbitals of the ligand ${ }^{45}$. A careful inspection of the pre-edge region reveals weak contributions at 5468.0 and $5469.5 \mathrm{eV}$ for each samples, related to $\mathrm{V}^{3+}$ and $\mathrm{V}^{4+}$ oxidation states

respectively. ${ }^{45,46}$ The contribution at $5469.5 \mathrm{eV}$ grows in intensity upon going from $\mathrm{LiV}^{3+} \mathrm{PO}_{4} \mathrm{~F}$ to $\mathrm{LiVPO}_{4} \mathrm{~F}_{0.92} \mathrm{O}_{0.08}$ and to "NaVPO${ }_{4} \mathrm{~F}$ ", thus confirming the increasing in the vanadium average oxidation state and the formation of local $\mathrm{V}^{\mathrm{IV}}=\mathrm{O}$ vanadyl-type environments.

\subsection{ELECTROCHEMICAL BEHAVIOR}

Electrochemical cells were cycled at $\mathrm{C} / 50$ between 2.50 and $4.50 \mathrm{~V}$ vs $\mathrm{Na}^{+} / \mathrm{Na}$. As shown in Figure 8 the specific capacity obtained during the first charge is limited to $20 \%$ of the theoretical one (i.e. 30 against $144 \mathrm{mAh} / \mathrm{g}$ ) and the amount of sodium reinserted is almost 
negligible, despite the morphology of the particles favorable to compete against the ionic conductivity intrinsically low. The value of the working potential associated to the $\mathrm{V}^{3+} / \mathrm{V}^{4+}$ redox couple cannot be determined due to the very small reversible capacity, the high polarization and the absence of a clear voltage plateau.

In order to determine if sodium extraction is kinetically or thermodynamically limited, the chemical oxidation of the material was performed using an excess of $\mathrm{NO}_{2} \mathrm{BF}_{4}$ in acetonitrile during 7 days. As shown in Figure $\mathbf{S 5}$ in supplementary information, the SXRPD pattern of the material obtained can be indexed in a unit cell really close to that of the pristine phase, with only a small increase in the cell parameters $(a=6.5691(1) \AA, b=8.4464(1) \AA, c=7.3780$ (1) $\AA, \beta=$ $117.847(1)^{\circ}, V=361.968(6) \AA^{3}$ against $a=6.5646$ (1) $\AA, b=8.4406$ (1) $\AA, c=7.3727$ (1) $\AA, \beta=$ $117.847(1)^{\circ}, V=361.208(6) \AA^{3}$ for the pristine material) and an occupancy of $0.92(3)$ for the $4 \mathrm{e}$ $\mathrm{Na}$ site that leads to a BVS value for the vanadium slightly higher than that observed in the pristine material (i.e. 3.33(1) vs 3.11(2)) .

The closely related lithiated phase, $\mathrm{LiVPO}_{4} \mathrm{~F}$, was also cycled in a sodium cell for comparison. Indeed, cycled versus Lithium, the electrochemical performances obtained for this material are excellent with a reversible capacity close to the theoretical one ${ }^{23,41,47}$. The electrochemical signature of $\mathrm{LiVPO}_{4} \mathrm{~F}$ versus sodium is given in Figure 8 and appears different from the one observed versus lithium. Indeed, besides a higher average potential, lithium extraction occurs according to a continuous change in the extraction voltage vs. $\mathrm{Na}^{+} / \mathrm{Na}$ whereas two successive plateaus are observed at 4.24 and $4.28 \mathrm{~V}$ vs. $\mathrm{Li}^{+} / \mathrm{Li}$. In both cases, one electron is exchanged. During the next discharge vs. $\mathrm{Na}^{+} / \mathrm{Na}$ only 0.3 electron is involved and the intercalation of $\mathrm{Na}^{+}$is thus limited. At the end of the charge the concentration ratio $\left[\mathrm{Li}^{+}\right] /\left[\mathrm{Na}^{+}\right]$ inside the electrolyte is close to $0.05\left(\sim 5 \mathrm{mg}\right.$ of the active material $\mathrm{LiVPO}_{4} \mathrm{~F}$ vs. $100 \mu \mathrm{L}$ of a $1 \mathrm{M}$ $\mathrm{NaPF}_{6}$ solution), and therefore $\mathrm{Na}^{+}$(and not Li ${ }^{+}$) is expected to be the cation reinserted in $\mathrm{VPO}_{4} \mathrm{~F}$. In order to understand the lithium extraction mechanism from $\mathrm{LiVPO}_{4} \mathrm{~F}$ into the sodiated electrolyte and to determine the nature of the cation re-inserted during the next discharge, 
laboratory X-ray diffraction was used to follow the electrochemical reaction under operando conditions.

Operando XRD patterns are shown in Figure 9. During the first part of the charge (between patterns \#1 and \#11), the intensity of the diffraction peaks associated to the pristine phase LiVPO ${ }_{4} \mathrm{~F}$ progressively decreases, whereas new lines that can be indexed with the unit cell parameters of $\mathrm{Li}_{0.67} \mathrm{VPO}_{4} \mathrm{~F}$ continuously grow in intensity. The XRD pattern \#11, recorded at $1 / 3$ of the charge (i.e. corresponding to a global composition of $\mathrm{Li}_{0.67} \mathrm{VPO}_{4} \mathrm{~F}$ ), is highlighted in red in Figure 9 and can be indexed considering the presence of three phases as reported in the supplementary information in Table S2: $\mathrm{LiVPO}_{4} \mathrm{~F}, \mathrm{Li}_{0.67} \mathrm{VPO}_{4} \mathrm{~F}$ and $\mathrm{VPO}_{4} \mathrm{~F}$. Spatial inhomogeneity in the electrode might be at the origin of the coexistence of 3 phases. Upon further $\mathrm{Li}^{+}$ extraction (between patterns \#11 and \#32), a two-phase process occurs between $\mathrm{Li}_{0.67} \mathrm{VPO}_{4} \mathrm{~F}$ and $\mathrm{VPO}_{4} \mathrm{~F}$. The fully-oxidized $\mathrm{VPO}_{4} \mathrm{~F}$ phase was refined in a similar unit cell (i.e. S.G: $\mathrm{C} 2 / \mathrm{c}$, $\left.a=7.1531(9) \AA, b=7.1153(6) \AA, c=7.220(9) \AA, \beta=118.096(4)^{\circ}, V=319.77(6) \AA^{3}\right)$, close to the previously reported when obtained by Lithium deintercalation from $\mathrm{LiVPO}_{4} \mathrm{~F}$ in a $1 \mathrm{M} \mathrm{LiPF} 6$ electrolyte $^{48}$. No significant difference is observed in the phase diagram stabilized during Lithium extraction from $\mathrm{LiVPO}_{4} \mathrm{~F}$, whatever the nature of the salt $\left(\mathrm{LiPF}_{6}\right.$ or $\left.\mathrm{NaPF}_{6}\right)$ in the electrolyte and the negative electrode ( $\mathrm{Li}$ or $\mathrm{Na}$ ) used. The phase diagram itself thus does not provide any information which could explain the difference observed between the first electrochemical charges obtained for the $\mathrm{LiVPO}_{4} \mathrm{~F} / / \mathrm{Li}$ and $\mathrm{LiVPO}_{4} \mathrm{~F} / / \mathrm{Na}$ cells. Nevertheless, a $\mathrm{Li}^{+} / \mathrm{Na}^{+}$exchange could occur at the interface between the Li-rich electrode material and the $\mathrm{Na}$ rich liquid electrolyte. The formation of such interphase could modify the potential at the extreme surface of the particles during the lithium deintercalation, and thus explain the different voltage profile vs. $\mathrm{Na}^{+} / \mathrm{Na}$.

The X-ray diffraction patterns recorded during the next discharge highlight the recovering of the phase $\mathrm{LiVPO}_{4} \mathrm{~F}$, and surprisingly not the formation of the phase $\mathrm{NaVPO}_{4} \mathrm{~F}$ (or $\mathrm{Na}_{x} \mathrm{VPO}_{4} \mathrm{~F}$ ) despite a $\mathrm{Na}^{+} / \mathrm{Li}^{+}$ratio inside the electrolyte close to 20 . Indeed, no Bragg positions related to the monoclinic cell of $\mathrm{NaVPO}_{4} \mathrm{~F}$ could be detected, whereas other Bragg positions were observed, in good agreement with the cell parameters of $\mathrm{LiVPO}_{4} \mathrm{~F}$ (comparison given in 
Table S2, those obtained at the end of the discharge are really close to those of the pristine material $\mathrm{LiVPO}_{4} \mathrm{~F}$ ). These results suggest that no $\mathrm{Na}^{+}$cations could be inserted into $\mathrm{VPO}_{4} \mathrm{~F}$ during the discharge. The limited discharge capacity and high polarization are probably due to the lack of $\mathrm{Li}^{+}$cations at the interface electrode/electrolyte and the insertion reaction is thus limited. We can conclude that the poor electrochemical properties delivered by the $\mathrm{NaVPO}_{4} \mathrm{~F}$-type material are due to the intrinsic low sodium mobility in Tavorite structure, in agreement with the BVEL study mentioned above.

\section{CONCLUSION}

We report for the first time the synthesis of a Na-based VIII-rich phase crystallizing in the Tavorite-like structure. This material was obtained in hydrothermal conditions as needle-like shape particles. Its composition was shown to be $\mathrm{NaVPO}_{4} \mathrm{~F}_{0.85} \mathrm{O}_{0.15}$, with the presence of vanadyl-type defects ( 15\%) and thus a mixed valence for vanadium $\left(\mathrm{V}^{3+} / \mathrm{V}^{4+}\right)$. Microstructural effects were identified through the anisotropic broadening of the X-ray diffraction lines. The presence of vanadyl-type environments as defects would in fact generate locally a shortening of the $\mathrm{V}-\mathrm{F}(\mathrm{O})$ distances, and thus strains, along the chains of $\mathrm{VO}_{4}(\mathrm{~F}, \mathrm{O})_{2}$ octahedra. This materials is electrochemically (quasi) inactive despite a suitable morphology. Indeed, bond valence energy landscape and operando X-ray diffraction of $\mathrm{LiVPO}_{4} \mathrm{~F}$ cycled versus sodium reveal that the electrochemical properties are inhibited by intrinsic low sodium mobility in such Tavorite framework.

\section{Acknowledgment}

The authors thank Michel Ménétrier, Marie Guignard, Patrick Rosa, Laetitia Etienne and Eric Lebraud at ICMCB and Matthieu Courty at LRCS for discussions and support in running some technical experiments, as well as ALBA (Barcelona, Spain) for Synchrotron X-ray diffraction experiments on MSPD beamline (proposal number 2015021236) and SOLEIL (Gif-sur-Yvette, France) for X-ray spectroscopy experiments on ROCK beamline (financed by the French National Research Agency (ANR) as a part of the "Investissements d'Avenir" program, reference: ANR-10- 
EQPX-45; proposal number 20160282). The authors also acknowledge FEDER, the Région Hautsde-France and the RS2E Network for the funding of EB's PhD thesis, as well as the financial support of Région Nouvelle Aquitaine and of the French National Research Agency (STORE-EX Labex Project ANR-10-LABX-76-01 and HIPOLITE Progelec project ANR-12-PRGE-0005-02).

\section{Author contributions}

E.B. carried out all the syntheses and electrochemical characterizations; E.B. was strongly involved in conducting all the other experiments, and in their analysis and interpretation mainly under the supervision of L.C., J.N.C. and C.M.; T.B. and D.C. conducted the NMR study and the theoretical calculations; P.S., V.P. and T.R. collaborate to the study of the electrochemical properties of $\mathrm{LiVPO}_{4} \mathrm{~F}$ in Na-ion batteries; L.D. conducted the microscopy study, L.B. the IR study, A.I. the XANES study, and F.F. the Synchrotron X-ray powder diffraction study. E.B., L.C., J.-N. and C.M. wrote the manuscript, and all authors discussed the experiments and final manuscript. 


\section{References}

(1) Grey, C. P.; Tarascon, J. M. Sustainability and in Situ Monitoring in Battery Development. Nat. Mater. 2017, 16, 45-56.

(2) Larcher, D.; Tarascon, J.-M. Towards Greener and More Sustainable Batteries for Electrical Energy Storage. Nat. Chem. 2015, 7, 19-29.

(3) Alekseenko, V.; Alekseenko, A. The Abundances of Chemical Elements in Urban Soils. J. Geochemical Explor. 2014, 147, 245-249.

(4) V. M. Goldschmidt. The Principles of Distribution of Chemical Elements. J. Chem. Soc. 1937, 655-673.

(5) Delmas, C.; Fouassier, C. and Hagenmuller, P. Structural Classification and Properties of the Layered Oxides. Physica 1980, 99B, 81-85.

(6) Yabuuchi, N.; Kajiyama, M.; Iwatate, J.; Nishikawa, H.; Hitomi, S.; Okuyama, R.; Usui, R.; Yamada, Y.; Komaba, S. P2-Type $\mathrm{Na}_{x}\left[\mathrm{Fe}_{1 / 2} \mathrm{Mn}_{1 / 2}\right] \mathrm{O}_{2}$ Made From earth-Abundant Elements for Rechargeable Na Batteries. Nat. Mater. 2012, 11, 512-517.

(7) Manthiram, A.; Goodenough, J. B. Lithium Insertion into $\mathrm{Fe}_{2}\left(\mathrm{MO}_{4}\right)_{3}$ Frameworks: Comparison of $\mathrm{M}=\mathrm{W}$ with $\mathrm{M}=$ Mo. J. Solid State Chem. 1987, 71, 349-360.

(8) Manthiram, A.; Goodenough, J. B. Lithium Insertion into $\mathrm{Fe}_{2}\left(\mathrm{SO}_{4}\right)_{3}$ Frameworks. J. Power Sources 1989, 26, 403-408.

(9) Xiang, X.; Zhang, K.; Chen, J. Recent Advances and Prospects of Cathode Materials for Sodium-Ion Batteries. Adv. Mater. 2015, 27, 5343-5364.

(10) Masquelier, C.; Croguennec, L. Polyanionic (phosphates, Silicates, Sulfates) Frameworks as Electrode Materials for Rechargeable Li (or Na) Batteries. Chem. Rev. 2013, 113, 65526591.

(11) Ponrouch, A.; Dedryvère, R.; Monti, D.; Demet, A. E.; Ponrouch, A.; Marcel, J.; Mba, A.; Croguennec, L.; Masquelier, C.; Johansson, P.; Palac, M. R. Environmental Science Towards High Energy Density Sodium Ion Batteries through Electrolyte Optimization. Energy Environ. Sci. 2013, 6, 2361-2369.

(12) Dugas, R.; Zhang, B.; Rozier, P.; Tarascon, J. M. Optimization of Na-lon Battery Systems Based on Polyanionic or. J. Electrochem. Soc. 2016, 163 (6), 867-874. 
(13) Jian, Z.; Han, W.; Lu, X.; Yang, H.; Hu, Y.; Zhou, J.; Zhou, Z.; Li, J.; Chen, W.; Chen, D.; Chen, L. Superior Electrochemical Performance and Storage Mechanism of $\mathrm{Na}_{3} \mathrm{~V}_{2}\left(\mathrm{PO}_{4}\right)_{3}$ Cathode for Room-Temperature Sodium-Ion Batteries. Adv. energy Mater. 2013, 3, 156-160.

(14) Saravanan, K.; Mason, C. W.; Rudola, A.; Wong, K. H.; Balaya, P. The First Report on Excellent Cycling Stability and Superior Rate Capability of $\mathrm{Na}_{3} \mathrm{~V}_{2}\left(\mathrm{PO}_{4}\right)_{3}$ for Sodium Ion Batteries. Adv. energy Mater. 2013, 444-450.

(15) Barker, J.; Saidi, M. Y.; Swoyer, J. L. A Comparative Investigation of the Li Insertion Properties of the Novel Fluorophosphate Phases, $\mathrm{NaVPO}_{4} \mathrm{~F}$ and $\mathrm{LiVPO}_{4} \mathrm{~F}$. J. Electrochem. Soc. 2004, 151 (10), A1670.

(16) Barker, J.; Saidi, M. Y.; Swoyer, J. L. A Sodium-Ion Cell Based on the Fluorophosphate Compound $\mathrm{NaVPO}_{4} \mathrm{~F}$. Electrochem. solid state Lett. 2003, 6 (1), 1-4.

(17) Zhao, J.; He, J.; Ding, X.; Zhou, J.; Ma, Y.; Wu, S.; Huang, R. A Novel Sol-gel Synthesis Route to $\mathrm{NaVPO}_{4} \mathrm{~F}$ as Cathode Material for Hybrid Lithium Ion Batteries. J. Power Sources 2010, 195, 6854-6859.

(18) Ruan, Y.; Wang, K.; Song, S.; Han, X.; Cheng, B. Electrochimica Acta Graphene Modified Sodium Vanadium Fluorophosphate as a High Voltage Cathode Material for Sodium Ion Batteries. Electrochim. Acta 2015, 160, 330-336.

(19) Lu, Y.; Zhang, S.; Li, Y.; Xue, L.; Xu, G.; Zhang, X. Preparation and Characterization of Carbon-Coated $\mathrm{NaVPO}_{4} \mathrm{~F}$ as Cathode Material for Rechargeable Sodium-Ion Batteries. J. Power Sources 2014, 247, 770-777.

(20) Jin, T.; Liu, Y.; Li, Y.; Cao, K.; Wang, X.; Jiao, L. Electrospun NaVPO ${ }_{4} F / C$ Nanofibers as SelfStanding Cathode Material for Ultralong Cycle Life Na-Ion Batteries. 2017.

(21) Law, M.; Balaya, P. NaVPO ${ }_{4} \mathrm{~F}$ with High Cycling Stability as a Promising Cathode for Sodium-Ion Battery. 2018, 10 (April 2017), 102-113.

(22) Song, J.; Xu, M.; Wang, L.; Goodenough, J. B. Exploration of $\mathrm{NaVOPO}_{4}$ as a Cathode for a Na-Ion Battery. Chem. Commun. 2013, 49, 5280-2282.

(23) Huang, H.; Faulkner, T.; Barker, J.; Saidi, M. Y. Lithium Metal Phosphates, Power and Automotive Applications. J. Power Sources 2009, 189, 748-751.

(24) Lin, Y.; Wen, B.; Wiaderek, K. M.; Sallis, S.; Liu, H.; Lapidus, S. H.; Borkiewicz, O. J.; Quackenbush, N. F.; Chernova, N. A.; Karki, K.; Omenya, F.; Chupas, P. J.; Piper, L. F. J.; Whittingham, M. S.; Chapman, K. W.; Ong, S. P. Thermodynamics, Kinetics and Structural Evolution of $\varepsilon$-LiVOPO 4 over Multiple Lithium Intercalation. chem. mater. 2016, 28, 17941805. 
(25) Bain, G. a.; Berry, J. F. Diamagnetic Corrections and Pascal's Constants. J. Chem. Educ. 2008, $85(4), 532-536$.

(26) Rodriguez-carvajal, J. Recent Advances in Magnetic Structure Determination by Neutron Powder Diffraction. Phys. B 1993, 192, 55-69.

(27) Boivin, E.; Chotard, J.-N.; Ménétrier, M.; Bourgeois, L.; Bamine, T.; Carlier, D.; Fauth, F.; Masquelier, C.; Croguennec, L. Oxidation under Air of Tavorite LiVPO $_{4} \mathrm{~F}$ : Influence of Vanadyl-Type Defects on Its Electrochemical Properties. J. Phys. Chem. C 2016, 120, 26187-26198.

(28) Ellis, B. L.; Nazar, L. F. Anion-Induced Solid Solution Electrochemical Behavior in Iron Tavorite Phosphates. Chem. Mater. 2012, 24, 966-968.

(29) Ravel, B.; Newville, M. ATHENA, ARTEMIS, HEPHAESTUS: Data Analysis for X-Ray Absorption Spectroscopy Using IFEFFIT. J. Synchrotron Radiat. 2005, 12, 537-541.

(30) Leriche, J. B.; Hamelet, S.; Shu, J.; Morcrette, M.; Masquelier, C.; Ouvrard, G.; Zerrouki, M.; Soudan, P.; Belin, S.; Elkaïm, E.; Baudelet, F. An Electrochemical Cell for Operando Study of Lithium Batteries Using Synchrotron Radiation. J. Electrochem. Soc. 2010, 157 (5), 606-610.

(31) Vaughey, J. T.; Harrison, W. T. A.; Jacobson, A. J.; Goshorn, D. P.; Johnson, J. W.; Technol, B. C. Synthesis, Structure and Properties of Two New Vanadium (III) Phosphates: VPO ${ }_{4}^{-}$ $\mathrm{H}_{2} \mathrm{O}$ and $\mathrm{V}_{1.23}\left(\mathrm{PO}_{4}\right)(\mathrm{OH})_{0.69}\left(\mathrm{H}_{2} \mathrm{O}\right)_{0.31} .0 .33 \mathrm{H}_{2} \mathrm{O}$. Inorg. Chem. 1994, 33, 2481-2487.

(32) Ren, M. M.; Zhou, Z.; Gao, X. P.; Liu, L.; Peng, W. X. LiVOPO 4 Hollow Microspheres : OnePot Hydrothermal Synthesis with Reactants as Self-Sacrifice Templates and Lithium Intercalation Performances. J. Phys. Chem. C 2008, 112, 13043-13046.

(33) Boivin, E.; Chotard, J.-N.; Ménétrier, M.; Bourgeois, L.; Bamine, T.; Carlier, D.; Fauth, F.; Suard, E.; Masquelier, C.; Croguennec, L. Structural and Electrochemical Studies of a New Tavorite Composition $\mathrm{LiVPO}_{4} \mathrm{OH}$. J. Mater. Chem. A 2016, 4, 11030-11045.

(34) Messinger, R. J.; Ménétrier, M.; Salager, E.; Boulineau, A.; Duttine, M.; Carlier, D.; Ateba Mba, J.-M.; Croguennec, L.; Masquelier, C.; Massiot, D.; Deschamps, M. Revealing Defects in Crystalline Lithium-Ion Battery Electrodes by Solid-State NMR: Applications to LiVPO ${ }_{4} \mathrm{~F}$. Chem. Mater. 2015, 27, 5212-5221.

(35) Bamine, T.; Boivin, E.; Boucher, F.; Messinger, R. J.; Salager, E.; Deschamps, M.; Masquelier, C.; Croguennec, L.; Ménétrier, M.; Carlier, D. Understanding Local Defects in Li-Ion Battery Electrodes through Combined DFT/NMR Studies: Application to LiVPO ${ }_{4} \mathrm{~F}$. J. Phys. Chem. C 2017, 121 (6), 3219-3227. 
(36) Stephens, P. W. Phenomenological Model of Anisotropic Peak Broadening in Powder Diffraction. J. Appl. Crystallogr. 1999, 32, 281-289.

(37) Rodríquez-Carvajal, J.; Roisnel, T. Line Broadening Analysis Using FullProf: Determination of Microstructural Properties. Mater. Sci. Forum 2004, 443-444, 123-126.

(38) MacTempas User Manual.

(39) Altomare, A.; Cuocci, C.; Giacovazzo, C.; Moliterni, A.; Rizzi, R.; Corriero, N.; Falcicchio, A. EXPO2013: A Kit of Tools for Phasing Crystal Structures from Powder Data. J. Appl. Crystallogr. 2013, 46, 1-5.

(40) Brown, I. D.; Altermatt, D. Bond-Valence Parameters Obtained from a Systematic Analysis of the Inorganic Crystal Structure Database I . Acta Cryst 1985, B41, 244-247.

(41) Ateba Mba, J.; Masquelier, C.; Suard, E.; Croguennec, L. Synthesis and Crystallographic Study of Homeotypic LiVPO ${ }_{4} \mathrm{~F}$ and $\mathrm{LiVPO}_{4} \mathrm{O}$. Chem. Mater. 2012, 24, 1223-1234.

(42) Adams, S. From Bond Valence Maps to Energy Landscapes for Mobile Ions in IonConducting Solids. Solid State Ionics 2006, 177, 1625-1630.

(43) Nakamoto, K. Infrared and Raman Spectra of Inorganic and Coordination Compounds. Part B: Applications in Coordination, Organometallic, and Bioinorganic Chemistry; John Wiley \& Sons, Inc., 1997.

(44) Marx, N.; Croguennec, L.; Carlier, D.; Bourgeois, L.; Kubiak, P.; Cras, F. Le; Delmas, C. Structural and Electrochemical Study of a New Crystalline Hydrated Iron(III) Phosphate $\mathrm{FePO}_{4} \cdot \mathrm{H}_{2} \mathrm{O}$ Obtained from LiFePO $4(\mathrm{OH})$ by Ion Exchange. Chem. Mater. 2010, 22, 18541861.

(45) Wong, J.; Lytle, F.W.; Messmer, R.P. and Maylotte, D. H. K-Edge Absorption Spectra of Selected Vanadium Compounds. Phys. Rev. B 1984, 30 (10), 5596-5610.

(46) Broux, T.; Bamine, T.; Fauth, F.; Simonelli, L.; Olszewski, W.; Marini, C.; Ménétrier, M.; Carlier, D.; Masquelier, C.; Croguennec, L. Strong Impact of the Oxygen Content in $\mathrm{Na}_{3} \mathrm{~V}_{2}\left(\mathrm{PO}_{4}\right)_{2} \mathrm{~F}_{3-\mathrm{y}} \mathrm{O}_{\mathrm{y}}(0 \leqq \mathrm{Y} \leqq 0.5)$ on Its Structural and Electrochemical Properties. Chem. Mater. 2016, 28, 7683-7692.

(47) Kim, M.; Lee, S.; Kang, B. Fast-Rate Capable Electrode Material with Higher Energy Density than $\mathrm{LiFePO}_{4}: 4.2 \mathrm{~V} \mathrm{LiVPO}_{4} \mathrm{~F}$ Synthesized by Scalable Single-Step Solid-State Reaction. Adv. Sci. 2015, 1-9. 
Boivin et al., submitted to J. Mater. Chem. A

(48) Ateba Mba, J.-M. a.; Croguennec, L.; Basir, N. I.; Barker, J.; Masquelier, C. Lithium Insertion or Extraction From/into Tavorite-Type LiVPO $_{4} \mathrm{~F}$ : An In Situ X-Ray Diffraction Study. J. Electrochem. Soc. 2012, 159 (8), 1171-1175. 
Boivin et al., submitted to J. Mater. Chem. A

\section{Table captions}

Table 1: Structural parameters obtained by Rietveld refinement of the structure of $\mathrm{NaVPO}_{4} \mathrm{~F}$ based on synchrotron XRPD Data.

Table 2: Bond lengths (below the diagonal) and angles (above the diagonal) in the coordination polyhedra of $\mathrm{V}^{3+}, \mathrm{Na}^{+}$and $\mathrm{P}^{5+}$ in $\mathrm{NaVPO}_{4} \mathrm{~F}$. The polyhedral distortion is calculated as $\Delta=\frac{1}{N} \sum_{i=0}^{N} \frac{(d i-\langle d\rangle) 2}{\langle d\rangle 2}$ with $\mathrm{N}$ the number of bond distances considered, $\mathrm{d}_{\mathrm{i}}$ the distance between the atom $i$ and the central atom of the polyhedron and $\langle d\rangle$ the average of the distances considered. 
Boivin et al., submitted to J. Mater. Chem. A

\section{Table 1}

\begin{tabular}{|c|c|c|c|c|c|c|c|}
\hline \multicolumn{8}{|c|}{$\mathrm{NaVPO}_{4} \mathrm{~F}$} \\
\hline \multirow{2}{*}{\multicolumn{2}{|c|}{$\begin{array}{c}\text { SG : } C 2 / c \\
Z=4\end{array}$}} & \multirow{3}{*}{\multicolumn{4}{|c|}{$\begin{array}{l}a=6.5646(1) \AA \\
b=8.4406(1) \AA \quad \beta=117.847(1)^{\circ} \\
c=7.3727(1) \AA \\
V=361.206(6) \AA^{3} \quad V / Z=90.302(6) \AA^{3}\end{array}$}} & \multirow{3}{*}{\multicolumn{2}{|c|}{$\begin{array}{c}\mathrm{R}_{\text {Bragg }}=3.73 \% \\
\chi^{2}=22.9\end{array}$}} \\
\hline & & & & & & & \\
\hline \multirow[b]{2}{*}{ atoms } & \multirow[b]{2}{*}{$\begin{array}{l}\text { Wickoff } \\
\text { position }\end{array}$} & & & & & & \\
\hline & & $x$ & $y$ & $z$ & occupancy & $B_{\text {iso }}$ & BVS \\
\hline $\mathrm{V}(1)$ & $4 c$ & $1 / 4$ & $1 / 4$ & 0 & 1 & $0.78(5)$ & $3.11(2)$ \\
\hline$P(1)$ & $4 e$ & 0 & $0.0671(4)$ & $1 / 4$ & 1 & $0.8(1)$ & $4.93(5)$ \\
\hline $\mathrm{O}(1)$ & $8 f$ & $0.2163(9)$ & $0.9619(6)$ & $0.3646(8)$ & 1 & $0.6(1)$ & $1.95(2)$ \\
\hline$O(2)$ & $8 f$ & $0.0333(9)$ & $0.1768(6)$ & $0.0984(8)$ & 1 & $0.7(1)$ & $1.99(3)$ \\
\hline$F(1)$ & $4 e$ & 0 & $0.6684(8)$ & $1 / 4$ & 1 & $1.6(2)$ & $1.34(1)$ \\
\hline $\mathrm{Na}(1)$ & $4 e$ & 0 & $0.4130(6)$ & $1 / 4$ & 1 & $3.3(2)$ & $1.26(1)$ \\
\hline
\end{tabular}


Boivin et al., submitted to J. Mater. Chem. A

\section{Table 2}

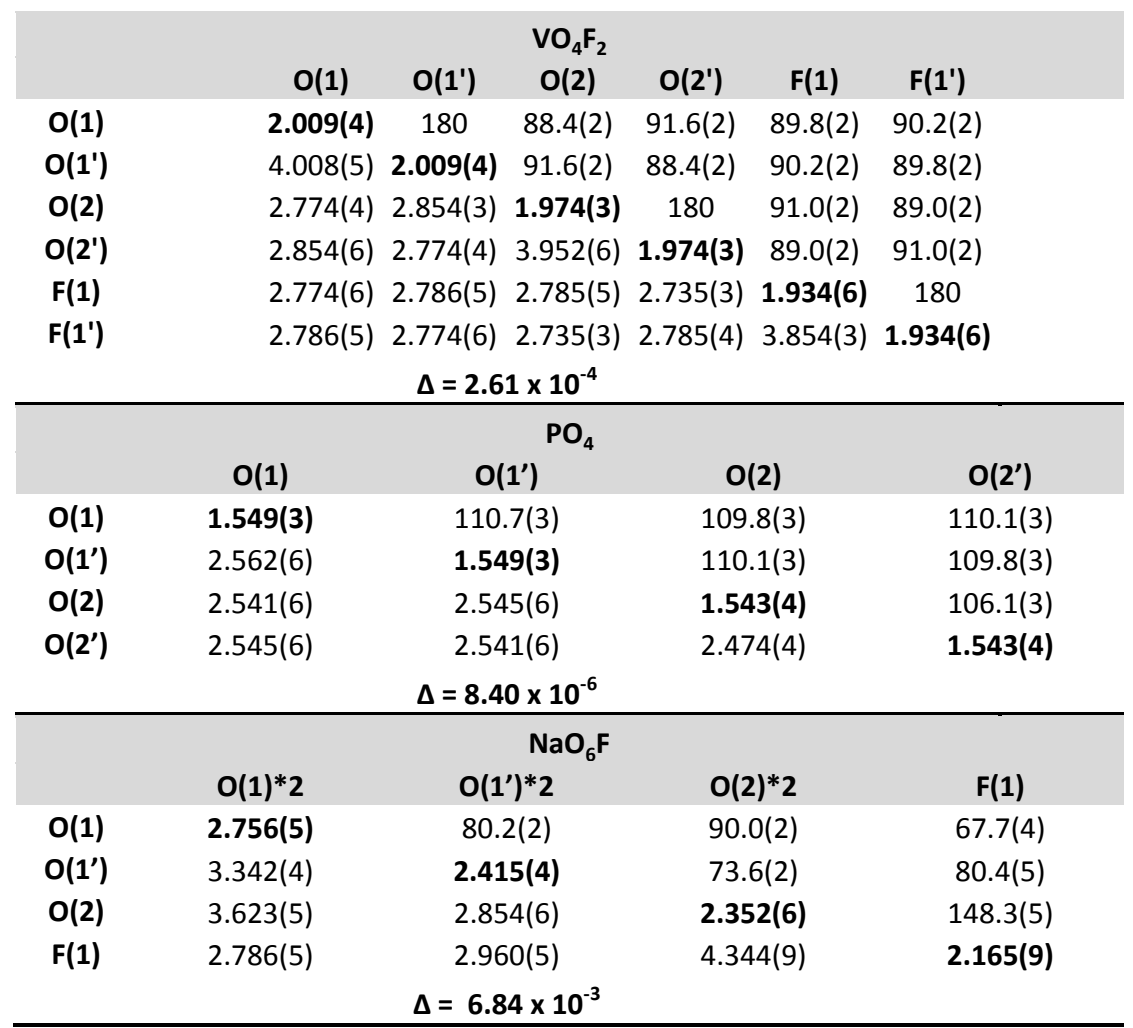




\section{Figure captions}

Figure 1: SEM images of the wide distribution of needle-like particles' sizes

Figure 2: Profile matching refinements of the diffraction pattern of $\mathrm{NaVPO}_{4} \mathrm{~F}$ using an isotropic size and strain model (a), an anisotropic size model (b) and an anisotropic strain model (c) as provided in the Fullprof suite. The agreement factors $\left(R_{B r a g g}, R_{p}\right.$ and $\left.\chi^{2}\right)$ as well as microstructural parameters, the width of microstrains distribution $(\varepsilon)$ and/or the cristallites sizes (D), are provided for each refinement.

Figure 3: a) TEM image of an isolated needle-like particle, representative of the whole sample. The higher magnification picture (b) and the resulting electron diffraction pattern (c). The enlargement of the selected region of $(b)$ is compared to the simulated high resolution image (d) where vanadium are represented as green circles, the sodium as yellow circles, phosphorus, oxygen and fluorine as orange circles.

Figure 4: Rietveld refinement of the structure of $\mathrm{NaVPO}_{4} \mathrm{~F}$ using an anisotropic strain broadening model as provided in the Fullprof suite. The observed intensities are plotted as red points, the theoretical Bragg positions are plotted as blue marks, calculated intensities and the difference between observed and calculated intensities are plotted as black lines.

Figure 5: (a) Structure of $\mathrm{NaVPO}_{4} \mathrm{~F}: \mathrm{VO}_{4} \mathrm{~F}_{2}$ octahedra in blue, $\mathrm{PO}_{4}$ tetrahedra in grey and sodium in purple. (b) Sodium diffusion pathway calculated thanks to Bond Valence Energy Landscape with an energy of $1.6 \mathrm{eV}$.

Figure 6: Diffuse reflectance infrared spectra of $\mathrm{NaVPO}_{4} \mathrm{~F}$ (blue), LiVPO ${ }_{4} \mathrm{~F}$ (black) and $\mathrm{LiVPO}_{4} \mathrm{~F}_{0.92} \mathrm{O}_{0.08}$ (grey, taken from ref. 27). The inset shows an enlarged graph of $\mathrm{PO}_{4}$ and $\mathrm{V}^{\mathrm{IV}}=\mathrm{O}$ stretching regions.

Figure 7: Vanadium K-edge XANES spectra of $\mathrm{NaVPO}_{4} \mathrm{~F}$, $\mathrm{LiVPO}_{4} \mathrm{~F}$ and $\mathrm{LiVPO}_{4} \mathrm{~F}_{0.92} \mathrm{O}_{0.08}$ taken from ref. 19. The inset shows an enlargement of the pre-edge region. 
Figure 8: (a) electrochemical signatures of $\mathrm{NaVPO}_{4} \mathrm{~F}$ (blue) and $\mathrm{LiVPO}_{4} \mathrm{~F}$ (black) obtained in half cells versus $\mathrm{Na}$ are compared to that of $\mathrm{LiVPO}_{4} \mathrm{~F}$ versus $\mathrm{Li}$ (grey) at $\mathrm{C} / 50$. The scales in voltage, vs. $\mathrm{Li}^{+} / \mathrm{Li}$ and vs $\mathrm{Na}^{+} / \mathrm{Na}$, were shifted from $0.3 \mathrm{~V}$.

Figure 9: Selected $2 \theta$ region of $X$-ray diffraction patterns recorded operando during cycling of $\mathrm{LiVPO}_{4} \mathrm{~F}$ vs $\mathrm{Na}$ at $\mathrm{C} / 50$ (1 pattern/90 minutes). XRD patterns corresponding to each part of the phase diagram $\mathrm{A}_{\mathrm{x}} \mathrm{VPO}_{4} \mathrm{~F}\left(\mathrm{~A}=\mathrm{Li}\right.$ or/and $\mathrm{Na}$ ) are shown: (a) biphasic mechanism between $\mathrm{LiVPO}_{4} \mathrm{~F}$ (black line) and $\mathrm{Li}_{0.67} \mathrm{VPO}_{4} \mathrm{~F}$ (red line), (b) biphasic mechanism between $\mathrm{Li}_{0.67} \mathrm{VPO}_{4} \mathrm{~F}$ and $\mathrm{VPO}_{4} \mathrm{~F}$ (orange line) and (c) biphasic process between $\mathrm{VPO}_{4} \mathrm{~F}$ and $\mathrm{AVPO}_{4} \mathrm{~F}$ (brown line) ( $\mathrm{A}=\mathrm{Li}$ and/or $\mathrm{Na}$ ). The XRD patterns corresponding of $\mathrm{NaVPO}_{4} \mathrm{~F}$ (blue line) acquired under the same conditions is also compared to the patterns obtained in-operando. 
Boivin et al., submitted to J. Mater. Chem. A

\section{Figure 1}
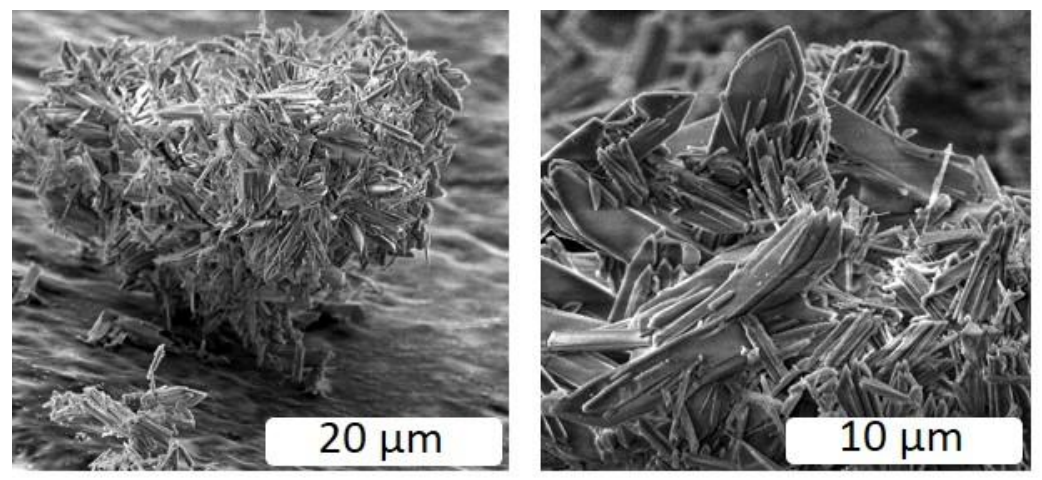


\section{Figure 2}

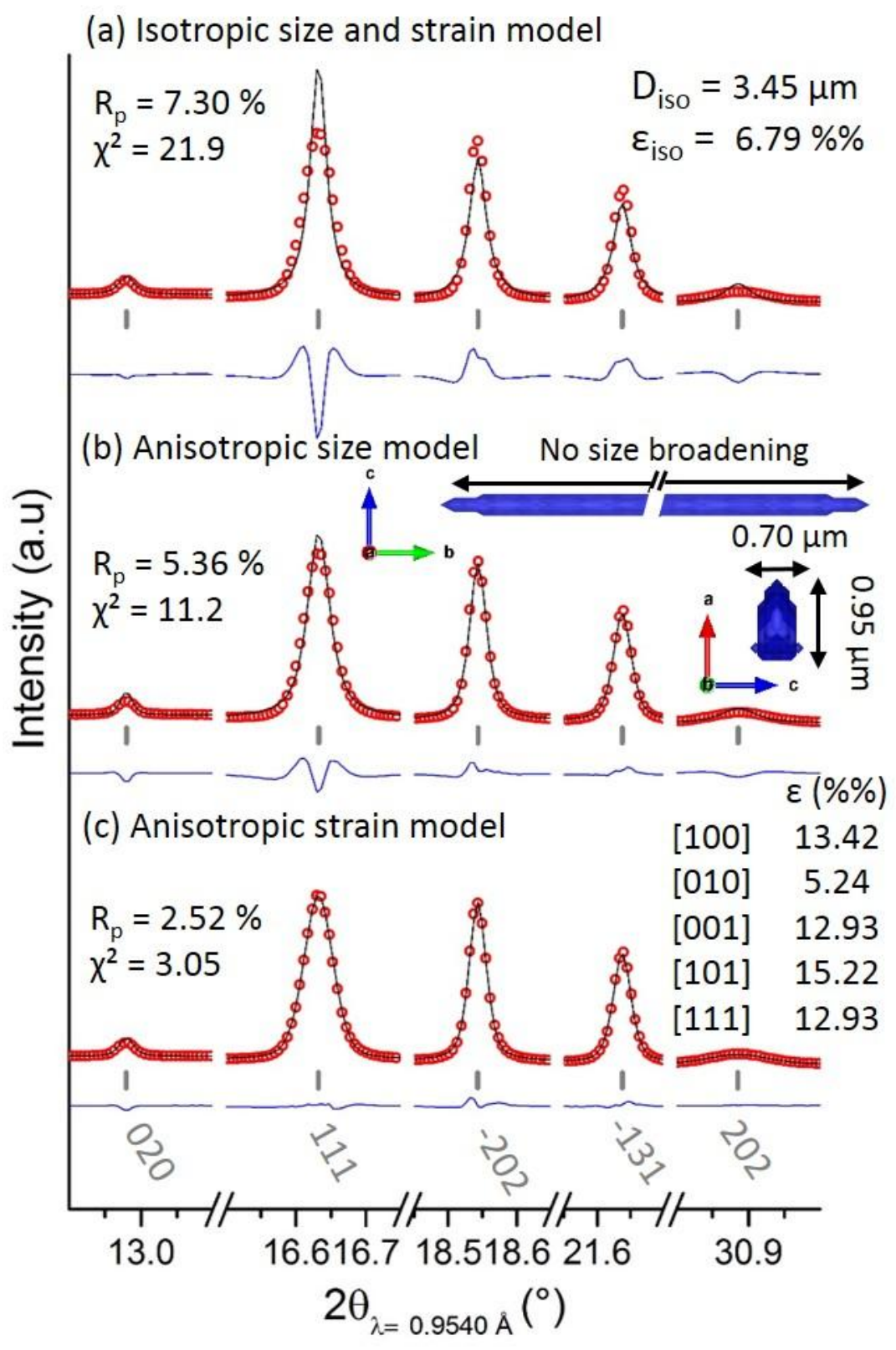




\section{Figure 3}

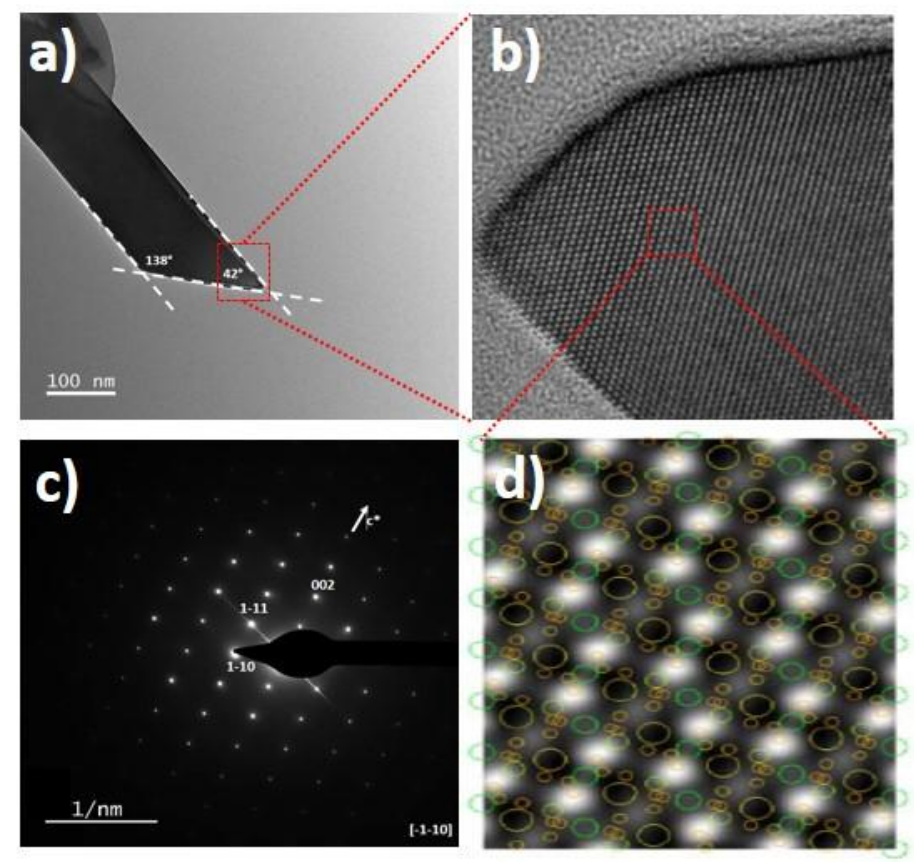


Boivin et al., submitted to J. Mater. Chem. A

\section{Figure 4}

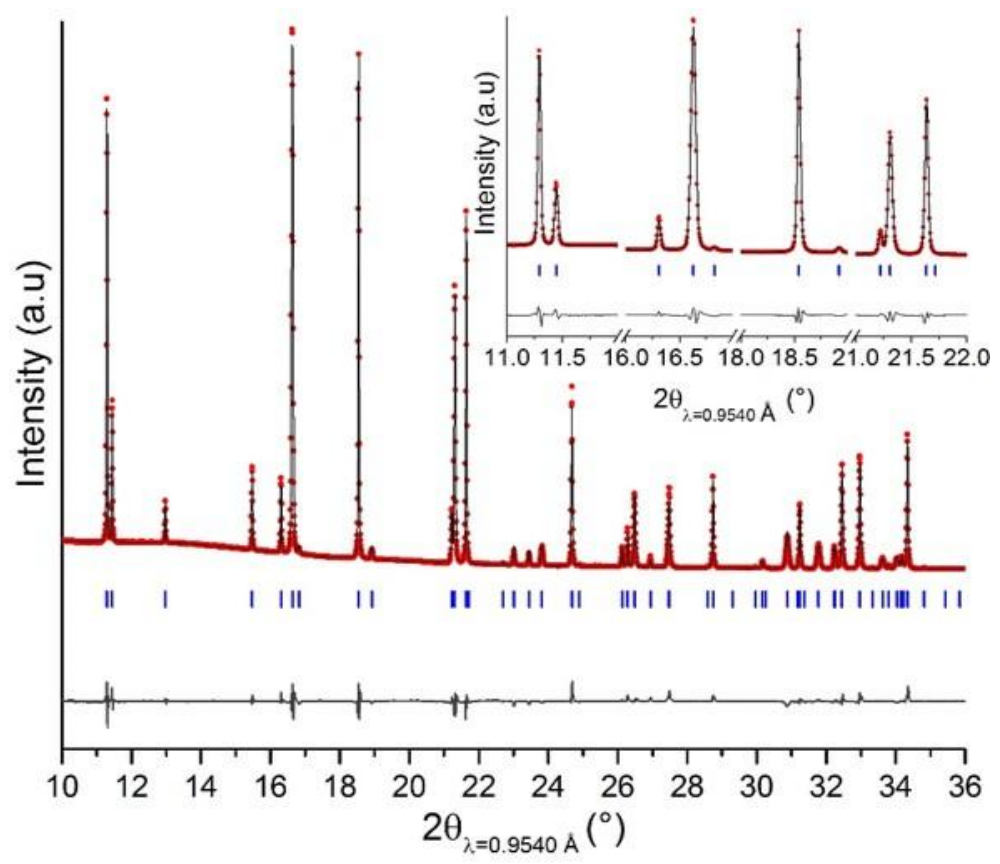




\section{Figure 5}
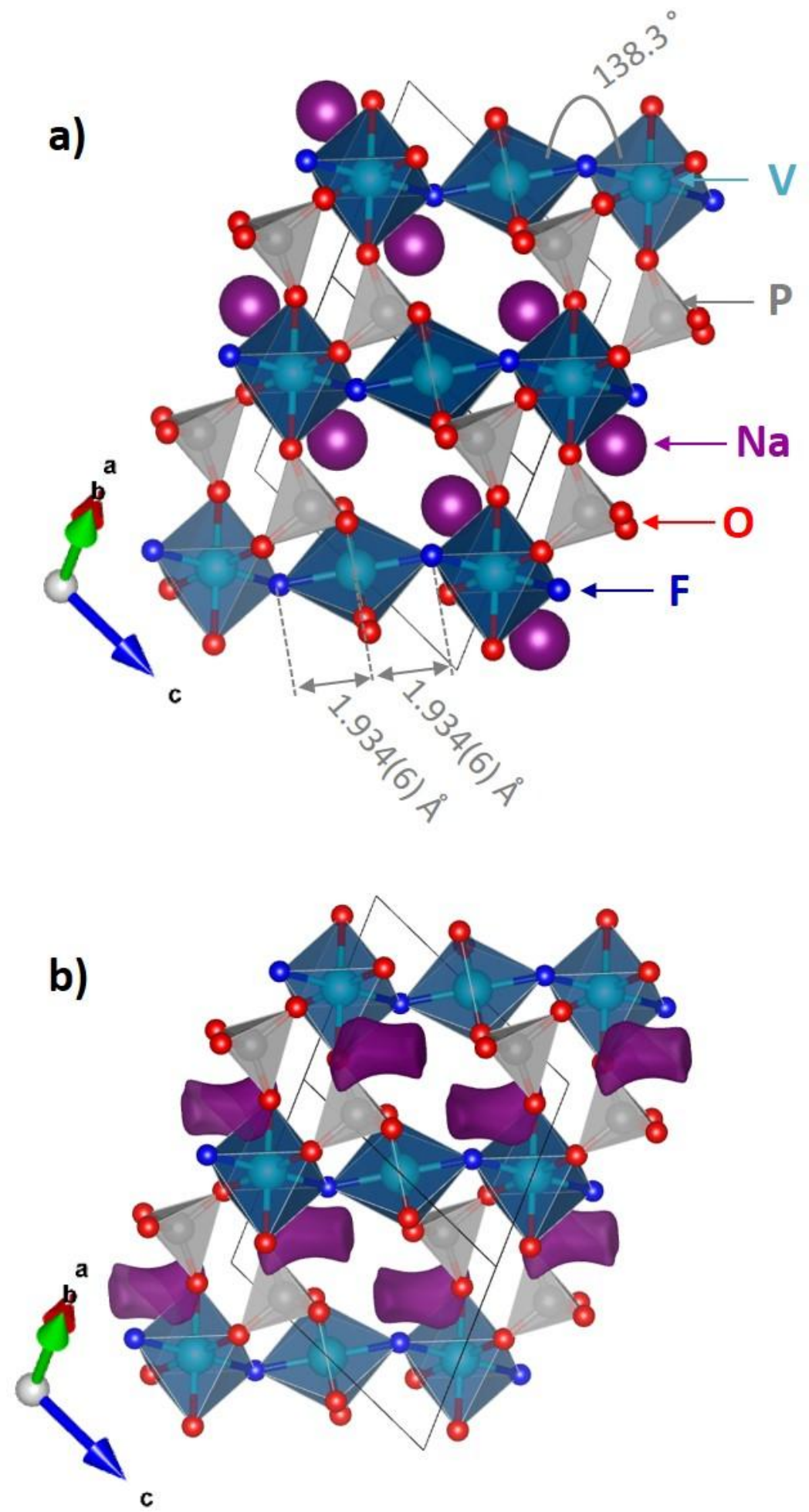
Boivin et al., submitted to J. Mater. Chem. A

Figure 6

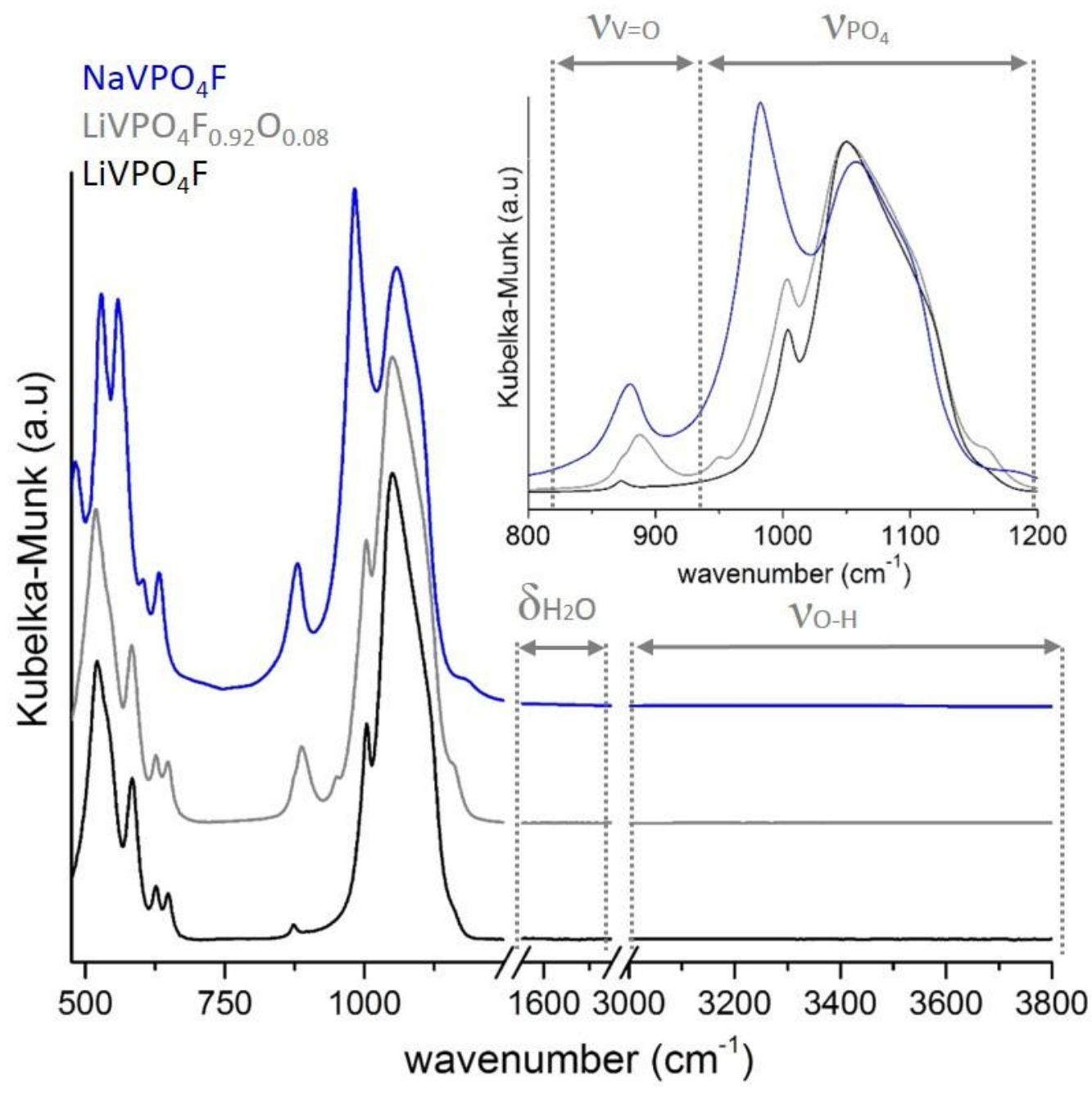


Boivin et al., submitted to J. Mater. Chem. A

\section{Figure 7}

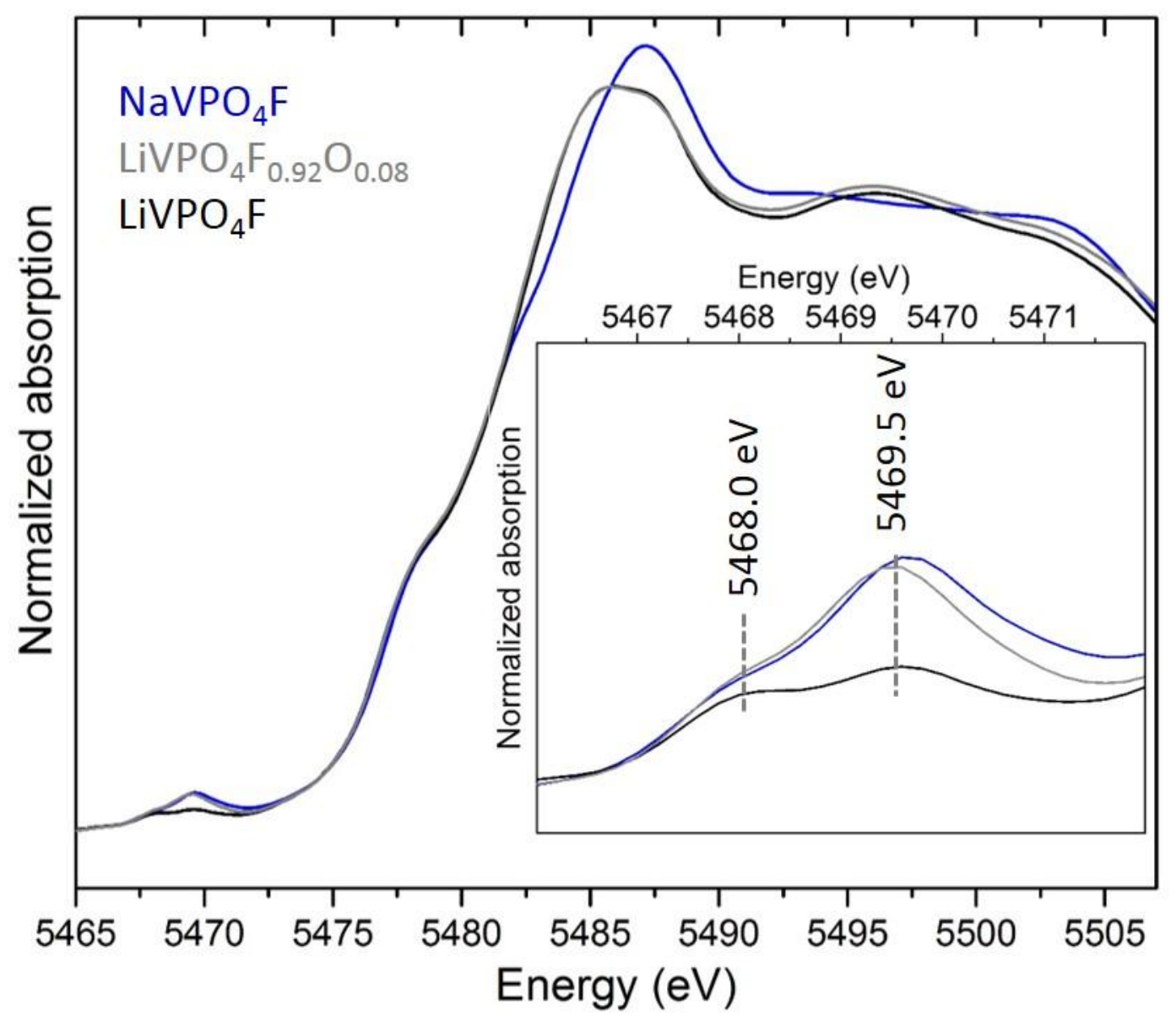


Boivin et al., submitted to J. Mater. Chem. A

\section{Figure 8}




Boivin et al., submitted to J. Mater. Chem. A

Figure 9

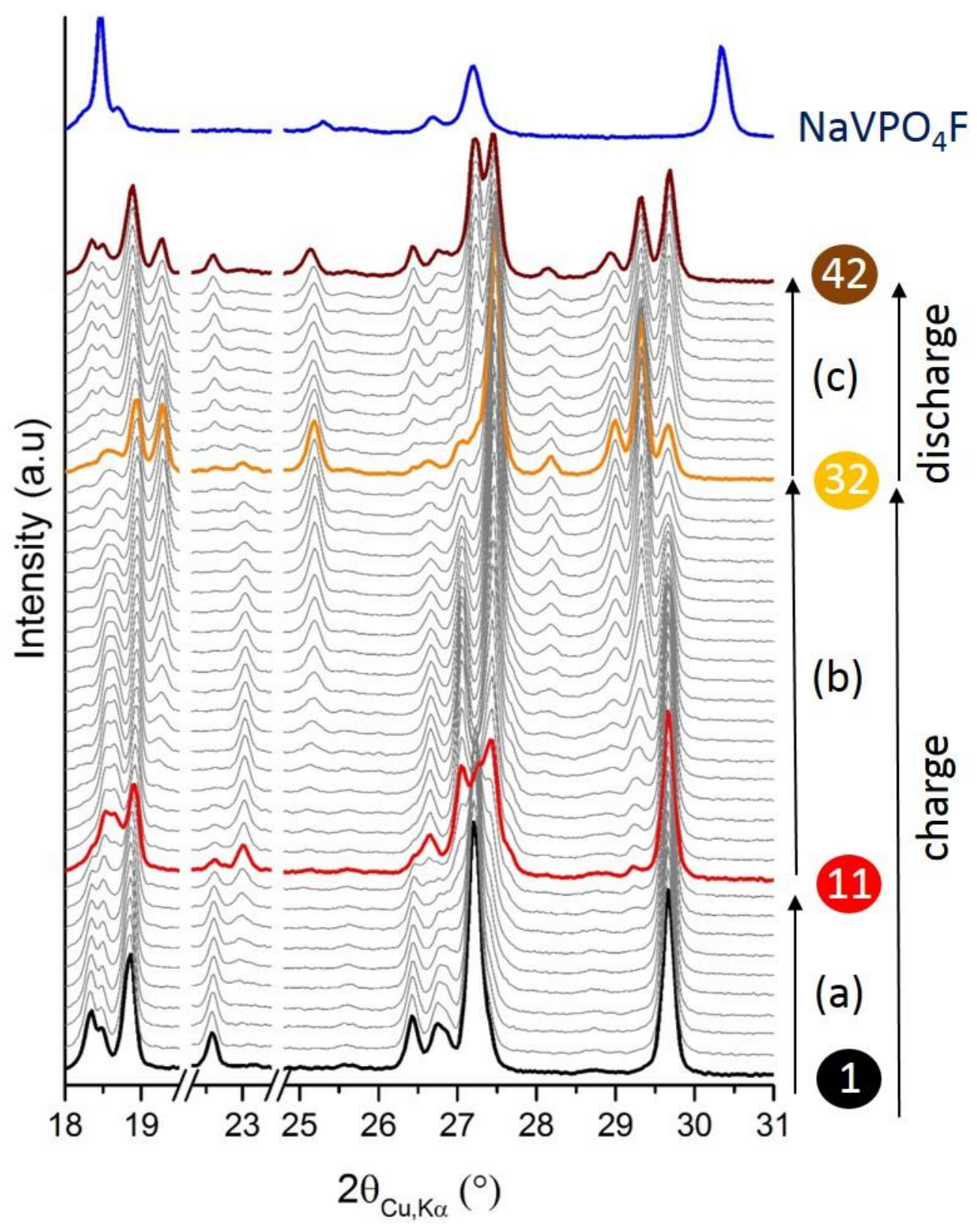

